\title{
Metodologický nacionalismus a pohled za jeho hranice: Budování národního státu, migrace a společenské vědy'
}

\author{
Methodological nationalism and beyond: \\ nation-state building, migration and the social sciences
}

\author{
Andreas Wimmer a Nina Glick Schiller
}

\begin{abstract}
Methodological nationalism is understood as the assumption that the nation/state/society is the natural social and political form of the modern world. We distinguish three modes of methodological nationalism that have characterized mainstream social science, and then show how these have influenced research on migration. We discover parallels between nationalist thinking and the conceptualization of migration in postwar social sciences. In a historical tour d'horizon, we show that this mainstream concept has developed in close interaction with nation-state building processes in the West and the role that immigration and integration policies have played within them. The shift towards a study of 'transnational communities' - the last phase in this process - was more a consequence of an epistemic move away from methodological nationalism than of the appearance of new objects of observation. The article concludes by recommending new concepts for analysis that, on the one hand, are not coloured by methodological nationalism and, on the other hand, go beyond the fluidism of much contemporary social theory.
\end{abstract}

KEYWORDS methodological nationalism, migration, nation-state, social sciences

Po prvotním zmatení nad povahou a rozsahem soudobých globalizačních procesů sociální vědci postoupili za rétorické zevšeobecňování úpadku národního státu a začali zkoumat způsoby, jakými se národní státy dnes spíše přetvářejí, než bourají. Stalo se až př́liš zřejmé, že národní státy a nacionalismus jsou s globalizací slučitelné. V době nárůstu globálních propojení jsme sledovali rozkvět nacionalismu a restrukturalizaci celé řady východoevropských států v souladu s národními hranicemi. Souběžnost těchto procesů nám dává intelektuální podnět k úvaze o mezích našeho pojmového aparátu. Nyní je jednodušší pochopit, že rozpor mezi budováním národního státu a globálními propojeními vnímáme proto, že předpokládáme svět rozdělený na nespojité a soběstačné národní státy. Další krok vyžaduje analýzu, jak koncept národního státu ovlivnil předchozí a stále ovlivňuje současné myšlení společenských věd, včetně našeho uvažování o transnacionální migraci.

Sociální studia. Fakulta sociálních studií Masarykovy univerzity, 1/2009. S. 11-47. ISSN 1214-813X.

1 Překlad převzat z: Wimmer, A.; Glick Schiler, N. 2002. „Methodological nationalism and beyond: nation-state building, migration and the social sciences." Global Networks, 2 (4): 301-334. (C) Blackwell Publishing Ltd 2002. Publikováno se svolením Copyright.com, www.copyright.com 
Naším cílem v tomto článku je pokročit tímto směrem tak, že prozkoumáme intelektuální potenciál dvou hypotéz. Ukazujeme, že procesy budování národních států zásadně formovaly způsoby vnímání a přijímání migrace. Tyto náhledy následně ovlivnily, ačkoliv ne zcela determinovaly, teorii a metodologii společenských věd, konkrétněji jejich diskurz o imigraci a integraci. Jako metodologický nacionalismus označujeme předpoklad, že národ/ stát/společnost je přirozenou sociální a politickou formou moderního světa. ${ }^{2}$

Článek je rozdělený do čtyř částí. První se zabývá čtyřmi druhy metodologického nacionalismu a ukazuje jejich význam pro společenskovědné myšlení. Poté demonstrujeme, jak metodologický nacionalismus ovlivnil a omezil bádání o transnacionální migraci. Ve třetí části načrtáváme historickou perspektivu, která nám umožní vidět budování národa, kontrolu a omezování přistěhovalectví a narůstající zájem sociálních věd o studium migrace jako vzájemně propojené procesy, odvíjející se v transnacionálním poli společenských sil. Čtvrtý oddíl se zaměřuje na poslední fázi tohoto procesu a popisuje nedávné vlny výzkumu globalizace a transnacionální migrace.

Až nyní, po ztrátě části moci národních států ve prospěch transnacionálních korporací a nadnárodních organizací, dokážeme ve zpětném pohledu nahlédnout, jakou podobu na sebe modernita vzala za posledních 200 let. Byla uzavřena v železné kleci nacionalizovaných států, které omezovaly a bránily rozvoji našich analytických schopností. V reakci na soudobé pojmové osvobození začaly vliv metodologického nacionalismu zkoumat historie (Bender 2001, Rodgers 1998), geografie (Taylor 1996), sociologie (Beck 2000) a antropologie (Glick Schiller 2000; Glick Schiller et al. 1992, 1995; Wimmer 1996a). Možná bylo těžší vidět svět ve třech rozměrech, když slunce stálo v zenitu. Večer se stíny prodlužují a umožňují nám vnímat prostředí v jasnějších obrysech.

V tomto soumraku zjišt'ujeme, v jak výrazné míře byl moderní svět vždy transnacionální, dokonce i v obdobích, kdy vrcholilo svazování a omezování většiny sociálních procesů národním státem. Transnacionalismus se spíše než nedávným dítkem globalizace jeví být

2 Za termín vděčíme Herminiu Martinsovi (1974: 276f.), který jej zmínil en passant ve svém článku o sociální teorii. Pojem užívá podobným způsobem jako my v tomto článku. Anthony Smith (1983: 26) zmiňuje tento koncept o desetiletí později, když poukazuje na skutečnost, že statistiky a také na nich založený společenskovědný výzkum činí z národních společností přirozenou jednotku analýzy. Termín je zcela jistě inspirován pojmem metodologického individualismu, který zavedl Schumpeter a zpopularizoval Friedrich von Hayek a ve svých pozdějších dílech Karl Popper. Metodologický individualismus, obvykle přisuzovaný sociologickému programu Maxe Webera, spočívá v analýze společnosti jako výsledku agregovaných rozhodnutí a činů jednotlivců, kteří představují základní jednotky sociálněvědné analýzy. Von Hayekovými slovy metodologický individualismus označuje přesvědčení, že „koncepce a názory zastávané jedinci (...) tvoří prvky, na jejichž základě musíme takříkajíc vystavět komplexnější jevy“ (von Hayek 1943: 38). Naše užití pojmu metodologický nacionalismus je ve srovnání s metodologickým individualismem poněkud širší. Nezahrnujeme do něj jenom pozitivní a výslovná tvrzení, že národy jsou základními jednotkami analýzy, ale rovněž práce, které: (1) následují tento princip, aniž by tak činily výslovně či dokonce vědomě; a/nebo (2) zanedbávají a přehlíží důležitost nacionalistické doktríny pro moderní svět. Přehlížení a ignorace představuje druh metodologického nacionalismu, který v klasických rozborech metodologického individualismu rozhodně nenachází obdoby. 
konstantou moderního života, skrytou před pohledem opanovaným metodologickým nacionalismem. Hodnota zkoumání transnacionálních komunit a migrace tedy nespočívá v objevu „něčeho nového“ - ačkoliv v současném intelektuálním prostředí př̌edstavuje tento př́stup velmi vděčnou výzkumnou strategii - ale v tom, že se stává př́spěvkem k opuštění perspektivy metodologického nacionalismu. Zevrubná reflexe dějin transnacionálních sociálních vztahů a jejich nedávného „objevu“ by se tedy mohla stát vhodným východiskem pro obecnější přehodnocení historie sociálních věd. Může nám pomoci rozvinout úhel pohledu „pozorovatele druhého řádu“, jak se jednou vyjádřil Niklas Luhmann, z něhož můžeme pozorovat jak sociální vědce pozorující sociální svět, tak i následky, které to na tento svět má, stejně jako způsoby, jimiž sociální síly ovlivňují náhled sociálních vědců.

\section{Tři druhy metodologického nacionalismu}

Náš výklad se soustředí na trendy, jež vnímáme jako hlavní a dominantní ve společenskovědném myšlení minulého století. Nevěnujeme se dobovým proudům, které hegemonnímu diskurzu protiřečily. Hlavně v časech umocněných globálních propojení se objevovaly teorie, jež tento vývoj odrážely a poskytovaly nástroje analýze nezabarvené metodologickým nacionalismem. Nejviditelnější z těchto proudů byla marxistická tradice $\mathrm{v}$ politické ekonomii, která vždy věnovala pozornost kapitalismu spíše jako globálnímu systému než jeho specifickým národním manifestacím, a zejména výzkumy imperialismu Rosy Luxemburg a dalších před první světovou válkou, kdy transnacionální oběh komodit, kapitálu a pracovních sil dosáhl svého prvního vrcholu. Wallersteinova teorie světového systému náleží ke druhé vlně teoretizace rozvíjející se $\mathrm{v} 70$. letech minulého století, kdy transnacionální spojení opět posilovala a množila se. Druhou a stejně důležitou vývojovou linií nezahrnutou do naší rozpravy je metodologický individualismus $\mathrm{v}$ jeho různých formách, $\mathrm{v}$ nichž analýza nespoléhá na výslovnou referenci k větším společenským celkům (například škola mezní užitečnosti a racionální volby v ekonomii a politické vědě či interakcionismus v sociologii).

Tyto přístupy však zůstaly nesourodé a neovlivnily program společenských věd stejným způsobem, jako proudy rozebírané $\mathrm{v}$ tomto článku. Epistemické struktury a programy hlavního proudu sociálních věd byly úzce spojeny se zkušeností utváření moderního národního státu a touto zkušeností formovány. Globální síly transnacionálního kapitalismu a imperialismu, které dosáhly svého vrcholu právě $\mathrm{v}$ době, kdy se společenské vědy formovaly jako nezávislé disciplíny, zanechaly v základních paradigmatických předpokladech těchto oborů jen málo stop a zrrídka se stávaly předmětem systematické reflexe.

Naším výchozím bodem je klasická sociální teorie, která výjimečně silně ovlivnila sociologickou tradici. Jak opakovaně poukázala celá řada autorů, slabinou klasické teorie modernity je výklad vzestupu národních států, stejně jako nacionalismu a etnicity (Esser 1988, Guiberneau 1997, Imhof 1997, A. D. Smith 1983, Thompson a Fevre 2001). Podle Marxe, Durkheima, Webera a Parsonse rostoucí diferenciace, racionalizace a modernizace společnosti postupně oslabily význam etnických a národních sentimentů. Většina klasické velké teorie byla zkonstruována jako sled socio-strukturálních typů (od feudalismu přes kapitalismus ke komunismu, od Gemeinschaft ke Gessellschaft, od organické k mechanické solidaritě, od tradiční k moderní společnosti a tak dále). Nacionalismus byl připsán ranějším stupňům 
kontinua sociální evoluce. Jako tradiční, pospolitostní, askriptivní, buržoazní či před-racionální fenomén byl nacionalismus považován za přechodnou fázi na cestě $\mathrm{k}$ moderní, racionalizované a individualizované třídní společnosti založené na zásluhách. Nacionalismus a patriotismus měly být brzy vymýceny proletářským internacionalismem (Marx a Engels) nebo post-vlasteneckým „idéal humaine“ (Durkheim; viz A. D. Smith 1983, Guiberneau 1997; o pozdějším více rozlišujícím pohledu Maxe Webera viz A. D. Smith 1983: 31-33).

Tato schémata se obrnila proti zdrcující a zjevné skutečnosti, že nacionalistická politika a konflikty utvářely dějiny 19. a 20. století. Tuto imunitu velké teorie zajištovala hierarchická dělba práce mezi akademickými disciplínami. Zkoumání vzestupu nacionalismu, národního státu a etno-nacionálních válek v Evropě 19. a raného 20. století bylo svěřeno historii - s několika výjimkami, jakou je například krátká esej, kterou Durkheim napsal bezprostředně po první světové válce. Skupinové identity a procesy budování národů mimo prostor Evropy a Spojených států byly učiněny doménami antropologie a později politické vědy. Tolik odsuzovaná neschopnost sociální teorie, která až do 80 . let 20 . století nedokázala postihnout význam a zdroje nacionalismu v moderním světě, může být částečně připsána této disciplinární dělbě práce, jež se ustanovila na začátku minulého století (Wimmer 1999).

Výjimečně silně se projevila ve společenských vědách ve Francii (Taguieff 1991: 46) a v Německu, kde sociolog Otto Hondrich (1992) cítil potřebu vyřknout veřejné nostra culpa za opomíjení nacionalismu jako předmětu sociální teorie (viz Radtke 1996). V anglosaském světě daly rané práce Deutsche, Kedouriho, Gellnera a Smithe o nacionalismu základ dobře zavedené výzkumné tradici rozvíjející se od 80 . let 20 . století, zejména v poli historické sociologie (cf. Thompson a Fevre 2001), nicméně bez většího vlivu na sociální teorii středního proudu.

Mnohem zásadnější příčinou tohoto mlčení o přetrvávající důležitosti národních principů však byl metodologický problém, na který před dvěma dekádami poukázal Anthony Smith (A. D. Smith 1983: 26). Přesvědčení, že nacionalistické formy inkluze a exkluze spojují naše společnosti, tvořilo neviditelné pozadí dokonce i toho nejsofistikovanějšího teoretizování o podmínkách modernity. Sociální vědy se nechaly ovládnout zdánlivou pririrozeností a daností světa rozděleného na společnosti hranicemi národních států (Berlin 1998). Billigův (1995) popis diskurzu každodennosti a každodenního jednání platí stejně tak dobře pro setkání velké teorie se sociálním světem: jelikož byly strukturovány podle principů národního státu, staly se tyto principy natolik rutinně předpokládanými a „banálními“, že nakonec zcela zmizely z dohledu.

Metodologický nacionalismus tedy zabránil skutečnému porozumění povaze a mezím moderního projektu. Dal vzniknout systematické slepotě vůči paradoxu, že modernizace vedla $\mathrm{k}$ ustanovení národních komunit $\mathrm{v}$ moderní společnosti, údajně ovládané principem výkonnosti. At' již Parsons a Merton, nebo Bourdieu, Habermas a Luhmann, ani jeden z těchto autorů se nějakým systematickým způsobem nezabývá nacionálním rámcem států a společností moderní doby. Co víc, tyto teorie modernity opomíjející koncept národa byly zformulovány $\mathrm{v}$ prostředí rychle se nacionalizujících společností a států a někdy, jako v př́padě Maxe Webera a Emila Durkheima, v předvečer nebo krátce po nacionalistických válkách.

Přehlížení národních rámců modernity je ovšem pouze jednou z forem metodologického nacionalismu. Druhou variantou, príznačnou pro empiričtěji orientované postupy sociálních 
věd, je považovat nacionální diskurzy, agendy, loajality a dějiny za samožrejmé, aniž by byly problematizovány či učiněny samostatnými objekty analýzy. Místo toho jsou národně ohraničené společnosti chápány jako přirozeně dané objekty studia. Následuje několik názorných př́íkladů naturalizace národního státu v různých disciplinárních tradicích.

Mezinárodní vztahy předpokládají, že národní státy představují adekvátní entity pro zkoumání mezinárodního světa. Zatímco anarchická povaha tohoto mezistátního systému a proměnlivá dynamika hegemonie a polycentrismu byly podrobně rozebírány, téměř žádné výzkumy se neptaly, proč se tento mezinárodní systém stal mezinárodním (jednou výjimkou je Mayall 1990). Podobně i poválečné studium nově nezávislých států považovalo budování národa za potřebnou, i když poněkud chaotickou složku dekolonizačního procesu (viz např́klad Wallerstein 1961). Zadání vystavět životaschopnou národní kulturu bylo zásluhou projekce vize budování západních národních států coby obecného modelu vnímáno jako zjevný důsledek dalších úkolů modernizace. Budování národa a utváření státu šly v dílech teoretiků modernizace, jako např́klad Lernera nebo Rostowa, přirozeně ruku v ruce, protože model národního státu představoval jediný myslitelný způsob politického uspořádání.

Ekonomie zkoumala hospodářství národně ohraničených entit nebo jejich vzájemné vztahy zprostředkované obchodem, toky kapitálu a podobně. Od vydání Pojednání o podstaté a pưvodu bohatství národì (An inquiry into the nature and causes of the wealth of nations) Adama Smithe (A. Smith 1983/1789) a - na kontinentu - veledíla Friedricha Lista Národní soustava politické ekonomie (Das nationale System der politischen Ökonomie) (List 1974/1856) se rozdělení domácí ekonomiky a zahraničních vztahů stalo vůdčím principem pro vývoj disciplíny. Je příznačné, že List nazval ekonomické procesy ohraničené národním státem termínem Volkswirtschaft, doslova hospodářstvím lidu. Smith v úvodu ke svému třísvazkovému magnum opus vysvětlil, že zamýšlí objasnit využití práce a kapitálu v různých, více či méně civilizovaných národech. John Maynard Keynes a další stěžejní političtí ekonomové 20. století zůstali věrni tomuto pohledu a považovali rozdíl mezi národním domácím hospodářstvím a mezinárodní zahraniční ekonomikou za samozřejmý.

Metodologický nacionalismus charakterizoval dokonce i pozdější pokusy překonat tato omezení perspektivy a popsat větší, nadnárodní hospodářské systémy. Zatímco od teorie závislosti se očekávalo překonání zaostření na jeden národ v americké teorii modernizace, pouze jej nahradila modelem vykořistování a dominance mezi národními státy, čímž implicitně reprodukovala národní stát jako základní jednotku analýzy (cf. Luton 1976).

Moderní dějiny byly z větši části, až do 90 . let 20. století a s pracemi Immanuela Wallersteina (1974) či Erica Wolfa (1982) jako významnými výjimkami, psány jako historie jednotlivých národních státu či jejich vzájemných vztahů - často již bez očividně nacionalistického cíle legitimizovat konkrétní projekt budování národa, jak tomu bylo do druhé světové války, avšak stále pod silným vlivem metodologického předpokladu, že konkrétní národ bude představovat stálou jednotku pozorování napříč všemi dějinnými transformacemi, onu „věc“, jejíž změny měla historie popsat. Tento náhled nadále vládne nově oživené historiografii,

Poslední české vydání pod tímto titulem - 2001. Praha: Liberální institut. Překlad Vladimír Irgl (pozn. překl.). 
dějinám umění a archeologii na mnoha východoevropských univerzitách, včetně těch řeckých (Karakasidou 1994; Niculescu v tisku).

V antropologii měl metodologický nacionalismus rozmanité a zákeřné následky, zejména poté, co tato disciplína opustila difuzionismus a přiklonila se $\mathrm{k}$ funkcionalismu jako svému vůdčímu paradigmatu. Antropologové často předpokládali, že jimi zkoumané kultury byly jednotné, organicky zasazené do konkrétních teritorií a v nich ukotvené, a reprodukovali tak obraz sociálního světa vlastní nacionalistickému myšlení, v němž je tento rozdělen na pevně ohraničené, kulturně specifické jednotky (Basch et al. 1994; Wimmer 1996a). Navíc raní antropologové definovali své pole bádání negativní extrapolací západní zkušenosti budování národních států: jejich privilegovaným předmětem se staly kmeny bez moderních států a etnické skupiny ve fázi před národem, přičemž systematicky „přehliželi““ vliv koloniálního režimu či národně-budovatelských agend na podřízené populace, které studovali.

Když antropologové pracovali v komplexních společnostech, včetně industrializovaných zemí Západu, metodologický nacionalismus opět určoval, co viděli. Antropologie etnických skupin v modernizujících se nebo průmyslových národních státech je měla sklon popisovat jako kulturně odlišné od „většinové“ populace vzhledem k jejich odlišnému historickému původu, včetně dějin jejich migrace, místo toho, aby nahlédla tyto rozdílnosti jako následek zpolitizování etnicity v kontextu samotného budování národního státu. Jenže klíčovou součástí projektu národního státu bylo definovat všechny populace neuznávané za reprezentantky „,národní kultury“ jako rasově a kulturně odlišné, a vytvořit tak jinakost, která napomáhala snahám o vybudování jednoty a identity (Glick Schiller 1999a, 1999b, 1999c; Williams 1989; Wimmer 2002). Antropologie tedy reprodukovala a naturalizovala pohled vycházející z centra vznikajícího národního státu.

Naturalizaci národního státu tedy můžeme najít $\mathrm{v}$ různých disciplínách a mnoha intelektuálních obměnách. Naturalizace vděčí za svou sílu rozdělení projektu společenských věd do přihrádek vícerých „,národních“ akademických domén, tedy procesu silně ovlivněnému nejenom samotným nacionalistickým myšlením, ale také institucemi, které organizují národní stát a řídí směrování společenskovědného myšlení na univerzitách, ve výzkumných institucích a vládních think-tancích. Je výmluvné, že dokonce i v současnosti je mimořádně těžké zabezpečit financování pro nadnárodní srovnávací výzkum, jak v poli migračních studií ukázala nedávná zpráva (Henke 2001). Hlavní výzkumné programy dotačních organizací se orientují na řešení národních problémů $\mathrm{v}$ hospodářství, politice a sociálních službách. Ve většině států jsou univerzity napojeny na národní ministerstva školství, jež upřednostňují výzkum a výuku témat „národního významu“. Akademie jsou - s výjimkami, jako např́ílad v Německu - obvykle „národními“ a někdy hrají důležitou roli v uchovávání kulturního dědictví národa, což je nejvíce patrné ve Francii. Když k tomu přidáme skutečnost, že téměř všechny statistiky a další systematické zdroje informací jsou vytvářeny vládními resorty národních států, a tedy berou národní obyvatelstvo, ekonomiku a politické zř́zení jako svůj předem daný předmět zájmu (Favell v tisku), je nám jasné, proč se naturalizování národního státu stalo přední formou metodologického nacionalismu v poválečných sociálních vědách.

Další druh naturalizování národního státu spočívá ve zlehčování role nacionalismu při budování moderních států tím, že se analyticky odděluje vzestup nacionalismu od rozvoje moderního státu a demokracie. Tímto způsobem se národní rámec zkušenosti budování 
moderního státu a demokratizace stává téměř neviditelným. Stát a národ se stávají dvěma samostatnými předměty zkoumání. Většina odborníků na nacionalismus se věnovala národu jako doméně identity. Národ je chápán jako lid, který sdílí společný původ a dějiny, což ukazuje jeho sdílená kultura, jazyk a identita (Calhoun 1997, McCrone 1998, A. D. Smith 1998). Naproti tomu „stát“ je obecně chápán jako svrchovaný systém vlády na jistém území. Na základě toho se v politologii coby hlavní proud vynořila teorie, která nahlíží stát jako neutrální hrací plochu pro různé zájmové skupiny - čímž z obrazu vylučuje skutečnost, že moderní stát vstoupil s nacionalistickým politickým projektem do symbiotického vztahu. To platí dokonce i pro sofistikovaná pojednání o modernizaci státu, jako je Giddensův (1995) Národní stát a násilí (Nation-state and violence).

Mnozí autoři, kteří překonali tuto segregaci a systematicky zkoumali vztahy mezi budováním národa a modernizací státu, upadli do jiných forem naturalizování národního státu. Pro Ernesta Gellnera ${ }^{4}$ je tak vzestup národního státu nevyhnutným důsledkem industrializace společnosti, jelikož poskytuje kulturně homogenní a komunikačně celistvý prostor, který zdynamizované hospodářství „,potřebuje“ (Gellner 1983). Pro Anthonyho Smithe (1995) jsou pouze národy a národní státy schopné poskytnout pocity bezpečí, identity a kulturní pohody, jež potřebujeme $\mathrm{v}$ rychle se měnícím a globalizujícím se světě. Až během poslední dekády byly tyto klapky metodologického nacionalismu sejmuty, když se podařilo překonat dichotomii státu a národa bez pádu do pasti naturalizace národního státu (Breuilly 1993, Mann 1993, Wimmer $1996 \mathrm{~b}$ a 2002).

Metodologický nacionalismus taktéž segreguje demokracii od nacionalismu. Dějinná a systémová logika, jež je spojuje, byla vymazána z naší historické paměti. Většina současných teorií a dějin demokracie, zejména pojednání politických filozofü, tuto vazbu zanedbává. Všímají si vnitřní dynamiky vyvíjejících se demokratických politických zřízení, a přitom ztrácejí ze zrretele nacionalistické principy, které historicky vymezily jejich hranice - s několika výjimkami, jakými jsou Snyderova (2000) nedávná publikace Od voleb k násilí (From voting to violence) či esej gruzínského filozofa Ghii Nodii (1992).

Následkem této dvojité segregace se nacionalismus jeví jako síla, která je dějinám budování západních států cizí. Místo toho je projektována na jiné - na krvežíznivé balkánské vůdce nebo na členy afrických kmenů, z nichž se stali nacionalisté. Představa budování západního státu se změnila na ne-národní, občanskou, republikánskou a liberální zkušenost, zejména v textech politických filozofů jako Rawls (Sen 1999). Segregace a přemístění jsou tudíž úzce spojeny. Etno-nacionalistické války a násilí, vytlačeny z dějin vlastního státu, se opět objevují v soudobých kulisách vzdálených míst. Nicméně to, co dnes označujeme jako etnické čistky či etnocidy a zhnuseně pozorujeme na „vždy problematickém Balkánu“ nebo v „tribalistické Africe“, byly ve skutečnosti konstanty evropské historie budování národů a formování států, od vyhánění cikánů za vlády Jindřicha VIII. nebo muslimů a židů za Ferdinanda a Isabely až po Bartolomějskou noc ve Francii nebo eufemisticky nazvanou „výměnu obyvatelstva“ mezi Tureckem a Řeckem po podepsání Lausannské smlouvy. Mnohé z těchto epizod zmizely

4 V češtině Gellner, A. 1993. Národy a nacionalismus, Praha: Josef Hříbal. Překlad Jiří Markus (pozn. překl.). 
z obecného povědomí - a možná zapomenuty být musí, jestli má být budování národa úspěšné, jak před více než sto lety naznačil Ernest Renan (1947/1882). ${ }^{5}$

Podívejme se nyní na třetí a poslední druh metodologického nacionalismu: na teritorializaci imaginace společenských věd a zúžení analytického záběru na hranice národního státu. Sociální vědy si vypěstovaly obsesi popisování procesů uvnitř hranic národního státu, vymezených vůči procesům vnějším, a v návaznosti na to pustily ze zřetele spojení mezi takto národnostně definovanými územími. Použijeme-li obraz vypůjčený od Giddense (1995), sít' sociálního života byla utkána v nádobě národní společnosti a všechno, co její hranice přesahovalo, bylo analyticky odstřiženo - podobně jako palačinka po nalití na horkou plotnu nabývá ohraničeného tvaru, odděleného od zbytku těsta, když přejdeme ke kuchyňské metafoře. Společnost jako nádoba zahrnuje kulturu, politické zřízení, hospodářství a ohraničenou sociální skupinu (Taylor 1996). Klíčové teoretické debaty se rozvíjely na téma relativní důležitosti těchto jednotlivých dimenzí pro strukturování sociální tkáně, přičemž následovníci Parsonse hlasovali pro kulturu a marxisté upřednostňovali ekonomiku, a dále kolem otázky, zda společnost determinuje konání jedinců, nebo naopak zda sociální struktury vznikají na základě individuálního jednání. Téměř vůbec nebylo zváženo, proč jsou hranice této společnosti jako nádoby narýsovány tak, jak jsou, a jaké následky vyplývají z tohoto metodologického omezení analytického horizontu - čímž byly přeshraniční vazby a procesy z obrazu zcela odstraněny.

Zajímavé je, že totéž platí i o společenskovědné analýze samotného procesu budování národního státu. Koncepce moderního státu a národní populace se historicky vyvíjely spíše $\mathrm{v}$ přeshraničních než teritoriálně omezených národních prostorech (Glick Schiller a Fouron 2001a). V mnoha př́padech byly tyto přeshraniční prostory vymezeny praxí a ideologií koloniální a imperiální nadvlády, zatímco ideje svrchovanosti lidu a republikánské nezávislosti se formovaly v přeshraničních sítích vzdělaných kruhů. Musíme uvažovat vně rámce dominantních národních diskurzů, abychom zhlédli tyto přeshraniční základy konkrétních projektů budování národních států, abychom spatřili dynamiku mezi anglickým ovládnutím Irska a anglickou národní identitou nebo spojitost mezi francouzskými idejemi občanství a civilizačními koncepty a francouzským koloniálním projektem (Lebovics 1992). Přijmutím převládajícího paradigmatu, které rozděluje věci státu na vnitřní národní záležitosti a mezinárodní záležitosti odpovídající vztahům mezi jednotlivými státy, se historie tohoto přeshraničního a transnacionálního budování národního státu stává neviditelnou. Psaní národních dějin tuto neviditelnost násobí tím, že uzavírá vyprávění do rámce státních hranic.

Třemi variantami metodologického nacionalismu, které jsme např́č disciplínami a obdobími odlišili v našem tour d 'horizon, jsou tedy přehlížení, naturalizace a teritoriální omezení. Tyto tři typy se protínají a vzájemně posilují a vytvářejí tak koherentní epistemickou strukturu, způsob nahlížení a popisování sociálního světa, který posiluje sám sebe. Tyto tři varianty nabývají v jednotlivých polích bádání většího či menšího významu. Přehlížení je dominantním modem metodologického nacionalismu ve velké teorii; naturalizace v „normální“ empirické vědě; teritoriální omezení ve výzkumu nacionalismu a budování států.

V češtině Renan, E. 2003. „Co je to národ?“. In Hroch, M. (ed.). Pohledy na národ a nacionalismus. Praha: Slon, s. 24-35. Překlad Marie Černá (pozn. překl.). 
Co má tohle všechno společné s migračními studiemi a s nárůstem literatury o transnacionální migraci? Další část ukazuje, jak metodologický nacionalismus ovlivnil poválečnou definici mezinárodní migrace a integrace imigrantů. Ve třetí části uvedeme tento statický obraz do pohybu a budeme si všímat, jak se věda po druhé světové válce skutečně vyvíjela a jak se to vztahovalo k procesům budování národních států.

\section{Vymezení předmětu migračních studií}

Abychom pochopili, jak metodologický nacionalismus ovlivnil výzkum migrace, nejprve podrobněji popíšeme vztah mezi nacionalistickým myšlením a modelem společnosti jako nádoby, který získal v poválečných sociálních vědách dominantní postavení. Na základě toho bude snadné pochopit, proč se migrace stala pro společenské vědy důležitým předmětem zájmu.

Moderní nacionalismus směšuje čtyři odlišné koncepty lidství, které se v raně novověké Evropě rozvíjely odděleně. Jsou to: lid jako svrchovaná entita, která vykonává politickou moc prostřednictvím některého $\mathrm{z}$ demokratických postupů; lid jako občané státu, kteří před zákonem užívají rovných práv; lid jako skupina závazné solidarity, rozšířená rodina spojená povinností vzájemně se podporovat; a lid jako etnická pospolitost, nediferencovaná odlišnostmi cti a prestiže, nýbrž sjednocená společným osudem a sdílenou kulturou. Tyto čtyři koncepty lidství jsou sloučeny do jednoho jediného lidu s velkým L. Demokracie, občanství, sociální jistota a národní sebeurčení představují vrcholy světového rádu národních států v jeho vyspělé podobě po druhé světové válce.

Jakmile je tento řád nastolen, nacionalistická představivost může být promítnuta na povrch Země a vepsána do území. Izomorfismus občanů, svrchovaných osob, skupin vázaných solidaritou a národa vyžaduje, aby se všechny korespondující teritoriální hranice sjednotily. Toto sjednocení hranic implikuje mnohem přísnější definici toho, co přináleží $\mathrm{k}$ danému prostoru a co spadá mimo něj. Přechod k územně fixovaným hranicím se zcela jistě kryje s ustavením centralizovaných království a předchází tedy nacionalizaci moderních států (Guernée 1986). Nicméně vztyčení hraničních sloupů, fyzické vyznačení hranic a sakralizace národního území jsou všechno jevy spojené se vznikem národních států (Nordman 1997), jelikož národní teritorium současně vyznačuje hranice svrchované populace, ohraničuje domovinu občanů, vymezuje dělicí linii mezi společenským řádem a chaosem a rozlišuje mezi domovem národa a divokostí ciziny. Nacionalisté tudíž z národního území dělají fetiš, svatostánek, který si zaslouží být bráněn za cenu prolití krve lidu.

Je snadné vidět paralely s modelem společnosti jako nádoby, který se rozvinul v sociálních vědách a převládl po druhé světové válce. Ekvivalence je téměř dokonalá: společenství občanů se zrcadlí v koncepci národní legislativy, svrchovaný lid v politickém systému, národ v kulturním systému a solidární skupina v sociálním systému, přičemž všechny hranice se shodují a společně tvoří kůži, která drží tělo společnosti pohromadě. Idea funkční integrace čerpající z obrazu tělesné stability, tak zdůrazňovaná ve standardním společenskovědném myšlení do 80. let 20. století, odrážela nacionalistické sloučení čtyř konceptů lidství do jednoho národního korpusu. To, co je Lid pro nacionalistu, je Společnost pro poválečného sociálního vědce. Oba sdílejí soubor základních předpokladů o tom, jak je ustaven společenský svět. 
Ted' by již mělo být jasné, proč pro budovatele národa, stejně jako pro poválečné sociální vědce, představují migranti objekt hodný výjimečné pozornosti a zkoumání. Podle nacionalistické doktríny a rovněž $\mathrm{v}$ souladu s modelem společnosti jako nádoby se imigranti musí jevit jako protiklady spořádaně fungujícího státu a společnosti, dokonce i ve společnostech, pro které někdejší imigrace představuje zakládající mýtus národa. Vidíme čtyři důvody, proč se migranti stávají zvláštním předmětem politik a také specializované oblasti výzkumu. Zaprvé narušují izomorfismus lidu, společenství svrchovaných a občanů. Přistěhovalci jsou vnímáni jako cizinci v komunitě sdílené loajality ke státu a sdílených práv zaručených tímto státem. Transnacionální migranti patrně zůstávají věrni jinému státu, jehož občany jsou a na jehož suverenitě se podílejí, a to do té doby, než jsou národním tělem pohlceni prostřednictvím asimilace a naturalizace. $V$ posledních letech se společenskovědný výzkum s obnovenou intenzitou, která pravděpodobně po 11. záŕí 2001 ještě vzroste, zajímal o politickou činnost a loajalitu imigrantů, což je téma odrážející zájem národního státu na dohledu, omezení a kontrole prisstěhovalecké populace.

Za druhé imigranti narušují izomorfismus lidu a národa. Jeví se jako skvrny na ryzích barvách národního tkaniva, připomínající nacionalistickým budovatelům státu a současně i sociálním vědcům etnické menšiny, které byly národním tělem „pohlceny“ prostřednictvím politik nucené asimilace a shovívavé integrace. Přistěhovalci tedy představovali obnovenou výzvu pro projekt budování národa a poukaz na křehkost jeho úspěchů - zejména v oblastech, kde nebyla představa národa nikdy plurální a kde sám národ sestával z bývalých imigrantů.

Dokonce i v přistěhovaleckých společnostech se poválečná migrační studia $\mathrm{v}$ první řadě zabývala měřením a podrobným zkoumáním kulturních rozdílů mezi př́slušníky národa a imigranty a popisem cest $\mathrm{k}$ asimilaci do národní skupiny, zkrátka popisem mechanismu úspěšného procesu utváření národa (Favell $\mathrm{v}$ tisku). Zdánlivě samozřejmé předpoklady metodologického nacionalismu vylučovaly problematizaci či zkoumání, zda imigranti kulturní různorodost de facto nezmenšují, spíše než zvětšují, jelikož referenční skupina národní pospolitosti mohla být trrídně a kulturně heterogenní, a tudíž obsahovat více diverzity než populace migrantů (Waldinger 2000).

Různé poválečné teorie integrace přistěhovalců, od asimilacionismu chicagské školy přes multikulturalismus a teorii rasizace a etnizace až k neoasimilacionismu, shodně předpokládaly, že relevantními entitami pro usouvztažnění jsou na jedné straně národ/stát/ společnost (ne nevyhnutně homogenní) a na druhé straně imigranti, již přicházejí zvnějšku tohoto národa/státu/společnosti. Toto pojetí základního problému nevděčí za svou sílu pouze funkcionalistické tradici, která určila integraci jako významný problém hodný zkoumání, ale taktéž metodologickému nacionalismu: integrace je př́slušníky jednoho národa vždy považována za vžitou, méně problematickou a méně křehkou.

Za třetí imigranti narušují izomorfismus lidu a skupiny solidarity. Není jim souzeno stát se částí systému sociálního zabezpečení, který národní pospolitost rozvinula v Nových údělech a Beveridgových plánech, protože přicházejí do národního prostoru solidarity „zvnějšku“. Jenže nemůžou být ze vznikajících systémů sociální péče ani zcela vyloučeni, protože tyto systémy jsou historicky a institucionálně svázány s pracovním procesem, pro nějž byli přistěhovalci nabíráni (Bommes a Halfmann 1994). Zásluhou tohoto napětí provázel jejich začlenění do sociálního systému dojem nelegitimnosti a zneužívání. Celé odvětví poválečných 
imigračních studií, zejména v Evropě, zkoumalo dopady přistěhovalectví na národní sociální systémy, analyzovalo nezaměstnanost imigrantů, sledovalo dynamiku vzniku slumů a ghettoizace a snažilo se pochopit kulturu chudoby, do níž imigranti domněle upadli. Přistěhovalec jakožto nečlen národní rodiny byl vnímán jako osoba náchylná dostat se na okraj společnosti a vystavená hrozbám osamělosti a hladovění. V souladu s logikou metodologického nacionalismu byli imigranti v kvantitativních výzkumech obvykle srovnáváni s „národními průměry“ ukazatelů jako prríjem a počet dětí na rodinu a s národním podílem nezaměstnaných a odkázaných na sociální dávky, přičemž se věřilo, že se jedná o adekvátní jednotky komparace (viz Vertovcův [1999] přehled studií o „sociální kohezi“). Zř́́dka jsou srovnáváni s částmi národní populace, které se jim blíží svým př́ijmem nebo vzděláním. Avšak když se taková srovnání uskuteční, přistěhovalci často dosahují lepších výsledků než domácí obyvatelstvo (Rumbaut a Cornelius 1995 pro USA a Bolzman et al. 2000 pro Švýcarsko).

Za čtvrté, $v$ očích budovatelů národního státu a rovněž sociálních vědců se každý pohyb přes státní hranice ${ }^{6}$ stává výjimkou z pravidla usazenosti uvnitř hranic národního státu. Výjimečnost přeshraničního usazení se je zcela evidentně spojená s teritorializací nacionalistické imaginace a se souběžným vznikem výše zmíněného modelu společnosti jako nádoby. Klíčové odvětví poválečných migračních studií a celá řada specializovaných výzkumných ústavů rozvinuly analýzu těchto přeshraničních pohybů, mechanismů, které je obousměrně podněcují (označované jako push-pull faktory), sítí řetězové migrace, které je udržují, a role sociálního a kulturního kapitálu při jejich omezování a řízení.

Tato literatura se zaměřuje pouze na migraci cizích státních př́slušníků, ne již na „zpáteční“ migraci krajanů, jako např́klad Aussiedler (většinou překládáno jako „etničtí Němci“) v Německu. Do roku 1989 byli Aussiedler zkoumáni folkloristy a historiky místo odborníků na migraci, kteří se soustředili výhradně na přistěhovalectví Ausländer (cizinců). A jenom přeshraniční migrace je předmětem migračních studií. „Vnitřní“ migrace občanů z jednoho města do druhého, z oblastí s klesající průmyslovou produkcí do vzkvétající metropole, není považována za problém vyžadující zvláštní pozornost a je bud' zcela přehlížena, anebo je vnímána jako součást výzkumu urbanizace, a tudíž traktována akademickými obory nesouvisejícími s migračními studiemi. Přeshraniční migrace se naproti tomu jeví jako anomálie, problematická výjimka z pravidla, podle něhož lidé zůstávají tam, kam ,patřri“, tedy v ,jejich“ národním státě. Poválečná migrační studia tudíž naturalizovala tuto př́islušnost, přesunula ji na pozadí společenskovědné argumentace a proměnila ji na jeden z jejích nezpochybnitelných axiomů.

Tyto čtyři body ukazují, jak velmi jsou migrační studia dítětem poválečné éry, v níž vyvrcholila moc národních států řídit, omezovat a ovlivňovat migrační pohyby i společenskovědné uvažování o nich. Tím, že popisovaly přistěhovalce jako potenciální bezpečnostní

6 Spojení jako national border, national frontier či national boundary, užívána v originálním znění této studie, překládáme jako „státní hranice“ vzhledem k ustálenosti tohoto spojení v českém jazyce. Anglický výraz national běžně nabývá v tomto i dalších kontextech význam, který se v češtině blíží spíše významu „státní“ než „národní“ (např. jako nerozvinuté substantivum může označovat „státního příslušníka“, „občana“). Při překladu se podle možnosti přidržujeme českých jazykových zvyklostí (pozn. překl.). 
hrozbu, jako kulturně odlišné, sociálně marginální a jako výjimku z pravidla vázanosti na konkrétní území, poválečné společenské vědy zrcadlily a současně, jak uvidíme v další části, legitimizovaly projekt budování národního státu, jehož cílem bylo ustanovit suverénní společenství občanů, homogenní národ, pospolitost vázanou solidaritou a teritoriálně vázaný stát.

\section{Fáze budování národa a diskurzy o přistěhovalectví}

Až dosud byla naše argumentace převážně konceptuální a abstraktní, využívající analogie mezi ideologiemi budování národního státu a pojmovými schématy společenských věd (v první části) a poválečných migračních studií (v druhé části). $\mathrm{V}$ části následující bychom rádi tyto vztahy situovali historicky. Načrtneme širši obraz vlivu jednotlivých etap utváření národního státu na jeho postoj $\mathrm{k}$ migraci a na způsob, jímž byly tyto fáze konceptualizovány v sociálních vědách. Uvidíme, že poválečný stav, kdy nacionalistická uzavřenost odpovídala společenskovědnému uvažování uzavřenému v nádobě, nebyl $\mathrm{v}$ žádném př́ípadě jedinou podobou, kterou na sebe tento vztah vzal.

Vyprávění tohoto př́běhu je zasazeno do světa, který se rozpíná a smrštuje mezi údobími globalizace a nacionalizace, ale stále - jak nám dovoluje pochopit perspektiva neomezená metodologickým nacionalismem - zůstává spojitým prostorem propojeným přeshraničními vztahy. Doufáme, že náš př́iběh přispěje k novému, celostnímu pohledu na souvislosti mezi budováním národního státu, migrací a společenskovědným projektem.

\section{Fáze l: Doba předválečná}

Rozlišujeme čtyři období, přičemž relevantní změny vykreslujeme rozmáchlými tahy štětce, abychom získali celkový pohled na scenérii, a data používáme pouze jako prribližné mezníky globálních dějinných proměn: 1870-1918, 1919-45, 1946-89, 1990-současnost, $\mathrm{s}$ tím, že poslední fázi se věnujeme v samostatné části.

Náš historický portrét začíná v období, které trvá od 70. let 19. století do první světové války. Tato belle époque byla časem dramatického růstu s vysokou poptávkou po práci, préerušovaného ekonomickými krizemi a rovněž význačnými obdobími stagnace a úpadku. Tyto fluktuace poznamenaly průmyslový rozvoj Evropy i Spojených států, s následky a souvislostmi pro Mexiko, Brazílii, Argentinu, Č́nu, Japonsko, Rusko a Turecko. Bylo to v této éře, kdy se průmysloví kapitalisté $\mathrm{v}$ honbě za vyššími zisky a jejich novými zdroji obrátili k novým formám globálního financování a investic. Vznikly obchodní společnosti jako důležití veřejní hráči s právy chráněnými státy, v nichž sídlily. Vytvářely monopoly a kartely a odstartovaly to, co jsme dnes schopni rozeznat jako intenzivní období globalizace (Held et al. 1999; Mittleman 1996a, 1999b; Wimmer 2001a).

Toto období provázely dva trendy, které byly vzájemně propojené komplexním a málo prozkoumaným způsobem. V první řadě se jednalo o dobu horlivého budování národního státu. Železnice pomohly rozvinout národní trhy pro zemědělské a průmyslové zboží. Národní poštovní služby přispěly k rozvoji národního hospodářství. Zákonná rovnost občanů skoncovala s posledními společenskými a feudálními omezeními ekonomické aktivity. Veřejné vzdělávací a zdravotní systémy formovaly vtělenou zkušenost veřejnosti s národním 
státem: mladí lidé se octli zavřeni ve třídách, kde se učili národním rituálům, a členové široké veřejnosti shledali, že jejich soukromá spotřeba a tělesné návyky se staly tématy veřejného vzdělávání a diskuse. V mnoha státech byla hlasovací práva rozširrena na tuto nově vzdělanou masu dospělých mužů. Zkrátka, došlo k vytvoření vrstvy občanů, svrchovaných osob a národa, čímž byl z velké části uskutečněn nacionalistický sen nastíněný v předchozí části.

Zatímco průmyslová odvětví se rozvíjela $\mathrm{v}$ mezích nacionalizujících se států, chráněna cly před zájmy kapitalistické konkurence, obchodní soutěž svázaná s koncepty národního zájmu odstartovala nové období kolonialismu. Toto byla epocha, kdy se evropské státy „rvaly“ o Afriku, stejně jako doba zvýšeného soupeření evropských států a Spojených států o kontrolu nad zdroji surovin v Karibiku, Latinské Americe a Asii. Byla to také éra, kdy se jako součást tohoto úsilí o zmonopolizování zdrojů surovin a získání pracovních sil pro jejich produkci rozvíjela praxe a teorie imperialismu.

Výsledkem těchto rozmanitých a vzájemně se ovlivňujících trendů v době, kterou charakterizovalo budování národních států a zároveň intenzivní globalizace, byla rozsáhlá pracovní migrace, která pokrývala celý svět a ve většině států narážela jen na malá nebo na žádná omezení. Svobodní dělníci, kteří svou pracovní sílu prodávali na nově vzniklém světovém pracovním trhu, tvořili část této migrace. Další část představovali smluvní nevolníci, ${ }^{7}$ kteří nahrazovali otroky na plantážích a stavbách železnic a dalších klíčových infrastrukturních projektů po celém světe, zejména v koloniích (Potts 1990). Poláci a Italové migrovali do severní Francie; Švýcarsko vítalo nové obyvatele různého původu; do Anglie přicházeli lidé z kontinentu; a průmyslový rozvoj Německa poháněly migrace z východu a jihu. Brazílie vítala přistěhovalce z Evropy, Blízkého východu a Japonska. Indičtí a čínští dělníci odcházeli do Karibiku a jižní a východní Afriky. Mexičané, Turci, Syřané a obyvatelé jižní a východní Evropy se přesouvali do Spojených států (Wyman 1993). Spojené státy, dnes stavěny do kontrastu s evropskými státy jako země přistěhovalců, ve skutečnosti jako první a na jistý čas i jediná země, vztyčily významnou překážku, když v roce 1882 na desetileté období přijaly Zákon o vyloučení Číňanů (Chinese Exclusion Act) a v roce 1892 ho obnovily. Německo, jehož území zahrnovalo bývalé části dřivějšího polského státu, po jistou dobu zevrubně kontrolovalo a hlídalo pohyb osob mluvících polsky (ovšem ne už Italů a dalších přistěhovalců), včetně držitelů německých pasů. Němečtí úřredníci pochybovali o loajalitě uživatelů polštiny

7 Originál užívá slovní spojení indentured labourers, které spolu se svými variantami (zejména indentured servants) nese v angličtině specifický význam, ale v češtině postrádá zavedený ekvivalent. Tímto termínem, pro který zde navrhujeme překlad „smluvní nevolníci“, se označují pracovníci, kteří byli právní listinou známou jako indenture zavázáni pracovat pro svého zaměstnavatele po jisté období (obvykle tři nebo sedm let) výměnou za stravu, dopravu, ubytování, oděv a další nezbytnosti. Po vypršení tohoto období měli být znovu svobodní. Někteří smluvní nevolníci se tímto způsobem zavázali dobrovolně, často za přepravu do Nového světa, kde chtěli hledat pracovní př́íležitosti, ale další byli $\mathrm{k}$ němu přinuceni, jako např. trestanci odsouzení $\mathrm{k}$ deportaci do kolonií, kteří se po vylodění nedokázali prokázat dostatečnými vlastními prostředky. Konkrétní životní podmínky těchto dělníků se velice lišily a v některých př́ípadech se mohly podobat situaci otroků. Na rozdíl od otroků však byla většina z nich evropského původu. Obzvlášt' běžnou formu osídlování a mobilizace pracovní síly představovala indenture v britských Třinácti koloniích v 17.a 18. století (pozn. překl.). 
$\mathrm{k}$ německému národnímu státu a viděli polský nacionalismus jako značnou hrozbu pro integritu čerstvě sjednoceného německého státu.

Avšak obecně to bylo období, kdy nebyly vyžadovány dokonce ani pasy a vstupní dokumenty. Systém pasů a víz, který evropské státy zavedly v první polovině 19. století, většina z nich zrušila poté, co jako první začala odstraňovat tyto překážky volného pohybu pracovních sil Francie v roce 1861. Do roku 1914 byly v Evropě fakticky všechny tyto dokumenty zrušeny (Torpey 2000). Některé státy se ze strachu z nedostatku pracovní síly snažily dělníkům zabránit $\mathrm{v}$ odchodu, ale tyto snahy byly poměrně neúčinné. Pracovníci migrovali do oblastí s rozvíjejícím se průmyslem a s nástupem špatných období se vraceli domů nebo se přesouvali jinam. Švýcarsko, Francie, Anglie, Německo, Spojené státy, Brazílie a Argentina vybudovaly industrializované ekonomiky s pomocí miliard pracovních migrantů, kteří pracovali v továrnách, na polích, ve mlýnech a v dolech.

Skutečnost, že migranti přicházeli a odcházeli, udržovali styky s domovem, posílali domů peníze na koupi země a na podporu rodného kraje, byla chápána jako běžná praxe. $\mathrm{Na}$ počátku tohoto období bylo pro prristěhovalce ještě stále snadné získat občanství, a mnozí pracovní migranti ho dostali dokonce i v Německu (cf. zákony o občanství před rokem 1913 in Borneman 1997: 98-102). Tento snadný př́stup k občanství odrážel skutečnost, že „lid“ dosud definovala především sdílená občanská práva a demokratická inkluze lid jakožto národ a jakožto skupina vázaná vzájemnou solidaritou nabyl na důležitosti až v další fázi budování národního státu. $\mathrm{V}$ souladu $\mathrm{s}$ absencí překážek pro migraci a s otevřenými režimy občanství E. G. Ravenstein (1889) v první systematické analýze migrace analyticky nerozlišoval mezi vnitřní a mezinárodní migrací. Místo toho Ravenstein přistupoval ke všemu pohybu lidí napříč územími jako k jedinému jevu, který determinovalo především rozložení ekonomických př́ležitostí ve fyzickém prostoru. Zjistil, že mezinárodní migrace se ř́́dila stejnými „zákony“ jako vnitřní migrace. Přesněji tvrdil, že migrace ve všech prrípadech sestávala $\mathrm{z}$ pohybů $\mathrm{z}$ venkova do města a $\mathrm{z}$ chudších oblastí do bohatších. Fakt, že v rámci mezinárodní migrace překračovali přistěhovalci státní hranice, představoval sice komplikaci pro výzkumníka hromadícího statistické údaje, ale nezakládal odlišnou sociální dynamiku.

Avšak budování národních států, jež počalo během této etapy globalizace, nakonec pomohlo prosadit konceptualizace „lidu“, které dramaticky ovlivnily migraci a změnily způsob její společenskovědné reflexe. „Etnická“ a/nebo „rasová“ definice lidství začaly nahrazovat „občanskou“ koncepci, původně utvářenou osvícenskými filozofy a konkretizovanou během americké, francouzské a haitské revoluce. Lid ted' znamenal v první řadě národ, jehož spojovaly společný původ a sdílená vlast, bez ohledu na to, kam se jeho členové zatoulali. Toto pojetí dávalo každému národu jeho vlastní národní charakter, jeho zvláštní povahu a vlast a také nárok na jeho místo na slunci. Tento nacionalizovaný pohled na lid se rozvinul v prostředí rostoucího soupeření o politickou dominanci v Evropě. Je možné jej najít ve všech dějinách budování národů, a to i přes často zdůrazňované rozdíly mezi Francií a Německem (Brubaker 1998, Silverman 1995). Národní šovinismus a rasismus legitimizoval jak budování koloniálních rríší během tohoto období, tak vyvrcholení onoho soupeření v první světové válce. Právě v kontextu této soutěže a velkého významu idejí národa a rasy zahájili budovatelé národního státu, včetně elit, politických vůdců, státních úředníků a intelektuálů, syste- 
matické snahy vymazat, popřít a sjednotit vnitřní kulturní a národní diverzitu přítomnou ve všech industrializujících se státech Evropy a obou Amerik.

$\mathrm{V}$ této stati se zabýváme zejména rolí společenských věd v této rekonceptualizaci. Sociální vědy se během tohoto období vynořily jako svébytná intelektuální iniciativa, která byla transformací pojmů národa a imigranta jednak utvářena, jednak k této transformaci přispívala. $\mathrm{V}$ tomto přechodu od občanského $\mathrm{k}$ národnímu pojetí lidu sehrála klíčovou roli folkloristika v Evropě a antropologie současně v Evropě a Spojených státech. Národy byly stále víc vnímány jako organické celky, jejichž živnou půdu tvořila čistá lidová moudrost (lore), tradice nebo vesnická ctnost sedláka, zemana či statkáře, ještě nezasaženého kosmopolitní moderností. Celosvětovou oblibu si získaly myšlenky národa jako rasy založené na krvi, které vstoupily do projektů budování národních států a do imperiálních ideologií, uživaných pro ospravedlnění koloniální expanze (Dikötter 1997). Sociologie zatím rozvinula ona velká schémata pokroku - od tradice k modernosti, od pospolitosti ke společnosti -, která učinila národní rámec těchto epochálních proměn neviditelným. Nicméně Durkheim a Weber, abychom se zmínili alespoň o dvou intelektuálních gigantech tohoto období, považovali za samozřejmé, že v soutěži s dalšími uchazeči o postavení nejcivilizovanějšího národa to bude jejich vlastní národně vymezená společnost, která bude na této cestě k budoucnosti postupovat nejvyšší rychlostí.

V rámci tohoto rostoucího odborného vědění zabarveného různými druhy metodologického nacionalismu neexistoval konceptuální prostor pro zkoumání skutečnosti, že utváření každého národního státu se neomezovalo na jeho územní hranice, ale naopak se odehrávalo v komplexní dialektice státu a jeho kolonií anebo obyvatelstva národního teritoria a jeho politického exilu a transmigrantů žijících v cizině. Pouze nedávno začal výzkum kolonialismu ilustrovat, jak rozlišování kolonizátora a kolonizovaného či přistěhovalců a domorodců ovlivňovalo budování takových národních států, jakými byly Francie, Anglie a dokonce i USA poté, co začaly zabírat kolonie a dozírat na Karibik (Gilroy 1991; Glick Schiller 1999a, 1999b; Hall et al. 2000; Lebovics 1992; Rafael 1995; Stoler 1989). Toto rozlišování sloužilo homogenizaci a zvýšení ceny národní kultury kolonizátorské země a také popularizaci myšlenky, že se jedná o jednotnou a jasně ohraničenou společnost, rozeznatelnou od podřízených populací pomocí rasových znaků.

Když se uchytily nacionalistické pojmy lidu a společnosti, začalo se měnit i pojetí přistěhovalců. Do konce století, ačkoliv tok migrace zůstal obecně neomezen, začali být migranti konceptualizováni jako lidé trvale přináležející ke své zemi původu. Mnoho aktérů přispělo k širrení této ideje, která se stala (mnoha způsoby) druhou stranou mince konceptualizování světa jako rozděleného na lidské skupiny tvořené národním společenstvím občanů a vládců. Přítomnost cizích občanů se tudíž stává, jak bylo rozebíráno v předchozí části, významnou hrozbou pro národní suverenitu a bezpečnost.

Naproti tomu, ale znovu v souladu s nově nacionalizovaným pojetím lidské existence, začaly zdrojové státy, včetně Itálie a Rakouska-Uherska, na své vystěhovalce pohlížet nadále jako na členy domovského společenství a očekávaly jejich návrat (Cinel 1982, Harrington 1982, Wyman 1993). Remitence z ciziny byly chápány jako významná součást hospodářství mnoha regionů. Státy vysílající emigranty založily instituce, aby je chránily a zároveň na ně dohlížely. Političtí exulanti odcházeli do světa z oblastí Evropy, v nichž sílily nacionalistické 
boje. Svoje zápasy dále vedli transnacionálně. Tito vůdcové viděli v exilu rozptýlené dělníky ze svého regionu jako své krajany a prostřednictvím organizovaných shromáždění, novin a náboženských a bratrských organizací se $\mathrm{v}$ nich snažili probudit nacionalistickou identitu a cítění. Vystěhovalečtí dělníci, kteří se přesouvali tam a zpět mezi svým domovským krajem a zemí imigrace jak v rámci Evropy, tak za Atlantikem v obou Amerikách, se začali účastnit těchto projektů budování národního státu probíhajících $\mathrm{v}$ jejich vlasti. Evropští i asijští přistěhovalci počali věřit, že stupeň uznání, jehož se jim dostane v cizině, se zvýší spolu se vzestupem moci a prestiže jejich mateřské země, a mnozí se stali vášnivými nacionalisty (Cinel 1982, Kwong 1987).

Všechny tyto transnacionální politické aktivity a tato angažovanost zdánlivě omlouvaly strach nacionalizujících se státu, že přistěhovalci podkopou stabilitu a teritoriální ohraničenost národa. Na konci tohoto prvního období zůstali imigranti vnímáni jako politicky nebezpeční a v národním a rasovém smyslu zásadně odlišní. Jejich př́tomnost byla nahlížena jako ohrožení izomorfismu společenství občanů, svrchovaných a státu. Ve stejné době političtí vůdcové v Evropě, kteří čelili politickým následkům intenzivní industrializace, obrovským nerovnostem mezi bohatými a chudými prohloubeným globalizačními procesy a také internacionálním revolučním hnutím dělníků, rozdmýchali oheň nedůvěry a nenávisti vůči cizím státním př́slušníkům, jenž se rozhořel naplno s propuknutím první světové války.

\section{Fáze II: Od první světové války po studenou válku}

První světová válka ukončila dobu svobodného pohybu pracovní síly a dalších jevů nesených intenzivní globalizací. Narušení ekonomik válkou a následnou rekonstitucí mnoha regionů do nově nezávislých států prispívalo k rostoucímu uzavírání hranic, které se ustavilo jako součást národní obrany těchto nově se nacionalizujících států. Současně probíhající proces utváření národních států - připomínající válečný stav -, plný etnických čistek a masového odnímání občanství, byl (a stále je) hlavní silou produkující uprchlíky (Sassen 1999; Zolberg 1983).

Masové vraždění ve jménu národní cti a nezávislosti dodalo myšlence osudové národní komunity nebývalou hodnověrnost, když učinilo z národní př́slušnosti otázku života a smrti nejen $\mathrm{v}$ zákopech, ale taktéž $\mathrm{v}$ širší společnosti. Rozeznávání př́itele od soka podle národního původu se stalo praxí a ideologií zdravého rozumu. Úspěch Únorové a Říjnové revoluce v Rusku podnítil dohled nad migranty jako potenciálními hrozbami pro národní bezpečnost a posílil rozlišování mezi národními a cizími idejemi a ideologiemi. Politická bouřlivost těchto let, kdy odpovědí na kapitalistickou recesi byly v Německu revoluční politika a ozbrojené povstání a ve Španělsku obnovení republiky, posílila úsilí nacionalistických států o dozor nad hranicemi a omezení pohybu politických a dělnických aktivistů.

Předchozí snahy vyvinout systém kontroly migrace byly přehodnoceny a nahrazeny historicky novými formami pohraničního dozoru. Od této doby každý potřeboval povolení, aby mohl vstoupit do země a přebývat v ní, což vedlo $\mathrm{k}$ dvojí dělbě; jednak mezi státními př́slušníky, kteří taková povolení nepotřebovali, a cizinci, a rovněž mezi legálními a ilegálními obyvateli států. Moc vydávat povolení soustředila do svých rukou centrální vláda. V USA tato pravomoc, o kterou ponejprv usilovaly různé státy, posílila postavení federální vlády a její 
roli ve vytyčování hranic mezi národem a jeho nepráteli. V Evropě začal nový vízový režim spojovat právo na pobyt v zemi s pracovním povolením, čímž fakticky definoval cizince jako sezónního dělníka. Mezi dvěma světovými válkami byl zkrátka institucionalizován celý centrální státní aparát dozoru, omezování a kontroly přistěhovalectví. Podle logiky ochrany hranic a rostoucích obav o bezpečnost byli imigranti od této doby přirozenými nepřáteli národa.

Transnacionální kontakty rodin $\mathrm{s}$ jejich členy $\mathrm{v}$ cizině mezitím narušila válečná devastace Evropy, která bránila posílání dopisů, peněz a balíků. Tím, že uprchlíci utíkali z válečných zón v Evropě a hranice se měnily, ztratili mnozí transmigranti žijící ve Spojených státech stopu svých rodin, někteří trvale. $V$ čase recese dále masivní nezaměstnanost a chudoba komplikovaly posílání remitencí. Lidé, kteří v obou Amerikách přicházeli o práci, se vraceli do domovů, jež v minulosti budovali ve svých domovských krajích. Současně omezení uvalená na imigraci do Spojených států účinně brzdila cestování tam a zpět, tak důležité pro přistěhovalecké rodiny, komunity a transnacionální budování národních států před válkou. Podobné změny se dotýkaly migrantů v Evropě.

Transnacionální politika a nacionalismus na dálku (long distance nationalism), tedy ideologie př́slušnosti, která rozšiřuje dosah vlastenecké politiky do transnacionálních sociálních polí, však během tohoto období přetrvávaly. Německá, italská a japonská vláda patřily mezi ty, které aktivně monitorovaly své občany $\mathrm{v}$ zahraničí a živily jejich věrnost $\mathrm{k}$ vlasti (Cinel 1982, Harrington 1982, Lesser 1999).

Krátké období mezi první a druhou světovou válkou přineslo zlom v prosazování metodologického nacionalismu a zároveň zrod našeho soudobého konceptu imigrace. Významnou roli v této konceptualizaci začaly hrát společenské vědy. Chicagská škola sociologie spojená s Robertem Parkem, Louisem Wirthem, Williamem I. Thomasem a Florianem Znanieckým spolu se St. Clairem Drakem rozvinuli první systematický př́stup k migraci.

Tito autoři sice věřili $\mathrm{v}$ přední význam nehodnotící sociologie, ale přesto jejich analytické modely obsahovaly řadu národních hodnot a norem určujících, jak má být prístěhovalectví chápáno. Ustanovili představu územně založeného státu se svou vlastní, stálou populací, proti níž stavěli do kontrastu migranty, které zobrazovali jako osoby na okraji společnosti, nacházející se $\mathrm{v}$ liminálním stavu, vykořeněné $\mathrm{z}$ jedné společnosti a přesazené do druhé. Prosazovali asimilaci - ne v návrzích plánů sociální intervence, ale prostřednictvím pojmu „cyklu rasových vztahü“, v němž by proces akulturace a asimilace přistěhovalců probíhal normálně a přirozeně během několika generací (Park 1950). Nenuceným užíváním výrazu „rasa“ akceptovali ztotožnění rasy a národa a zahrnuli jihoevropské a východoevropské imigranty, židovské přistěhovalce a Afroameričany do stejné kategorie osob rasově odlišných od většinových Američanů, i když v různé míre, což mělo údajně ovlivňovat rychlost jejich asimilace. Pohyb imigrantů byl v opozici ke společnosti přijímajícího státu, která se jevila jako fixovaná v homogenní národní kultuře. Zařazování Afroameričanů spolu s přistěhovalci do cyklu rasových vztahů je stavělo do pozice mimo národ, ačkoliv tvořili součást obyvatelstva USA od éry dobývání. Tento diskurzivní tah vyznačoval národ jako bílý a normalizoval dělbu podle barvy pleti (Lieberson 1980, Williams 1989).

Imigranti byli ted' viděni nejen jako bezpečnostní riziko, ale také jako ničitelé izomorfismu národa a lidu, a tudíž jako zásadní výzva pro pokračující projekt budování národa, která neustále nutí mašinerii asimilace vstřebávat nové vlny kulturní různorodosti. Stalo se 
těžším vnímat skutečnost, že budování národního státu je permanentní proces a že v rámci státních hranic existují významné třídní, kulturní, genderové a regionální odlišnosti. Národní integrace a kulturní homogenita národní společnosti se chápaly jako dané.

Tyto koncepce, jakkoliv zdánlivě ahistorické, byly z velké části produktem ústupu od globalizace, který nastal v době po první světové válce a v období velké recese 30 . let 20. století. Ve skutečnosti se nám zdá, že právě nižší stupeň globální ekonomické integrace během tohoto období vyvolal a ulehčil kvalitativní skok v budování národního státu a zrod modelu nádoby ve společenských vědách, jehož šíření napomohla chicagská škola. Sociální řád př́ítomný v rámci národního státu se stal samozřejmou premisou nové společenské vědy, stejně jako migračních studií. Brzy zapomenuta byla i existence období svobodné migrace pracovní síly v předchozích etapách globalizace. S tím, jak postupně převládl nový obraz migrace jako hrozby pro sociální řád, nejprve z očí a poté i z mysli zmizla rovněž sociální hnutí, jež tak snadno překračovala hranice a poháněla politický a intelektuální život, včetně dělnického internacionalismu, prvního ženského hnutí, panafrikanismu a různých forem nacionalismu na dálku (Gabaccia 2000, Gilroy 1993, Lemelle a Kelley 1994, Rodgers 1998).

Reálná data vyprodukovaná chicagskou školou a autory, které ovlivnila, ve skutečnosti poukázala na přetrvávající a významné transnacionální vazby většiny populací migrantů v rodinné, náboženské, ekonomické a politické oblasti. Park konkrétně dokumentoval vzory sociální kontroly a pomluv, které se transnacionálně šírily z rolnických vesnic do ulic New Yorku, úlohu přistěhovaleckého tisku v živení toho, co bychom dnes definovali jako nacionalismus na dálku, v populacích amerických imigrantů a ve zdrojových zemích emigrace, a také vzory pravidelných návratů a toky remitencí (Park 1974/1925; Schermerhorn 1949). Nicméně vzhledem k tomu, že jejich pohled omezoval model společnosti jako nádoby, všechna svědectví o transnacionálních spojeních definovali jako přechodné jevy, které se následkem přirozeného procesu asimilace vytratí.

\section{Fáze III: Studená válka}

V době po druhé světové válce, známé jako studená válka, se slepá skvrna změnila na slepotu, na téměř úplné vymazání historických vzpomínek na transnacionální a globální procesy, v rámci kterých se národní státy formovaly, a na roli migrace v této formaci. Teorie modernizace vytvářela dojem, jakoby se v západní Evropě a v USA národní identity a moderní státy rozvinuly v mezích svých teritorií spíše než ve vztahu ke globální ekonomice a tokům idejí. Rozšiřování Organizace spojených národů a udělení formální nezávislosti většině bývalých kolonií zpopularizovalo vizi, podle které se svět dělil na množství národních států, stejně významných a nezávislých. V terénu poválečné Evropy s jeho vysídlenými osobami a uprchlíky byl nový pořádek rychle nastolen nárokem na to, aby každý někam patřil. Ve Spojených státech četli školáci pohádky s ponaučením o „,̌lověku bez vlasti“ a pěli patriotické písně. Po celém světě se občanská výchova stále více ztotožňovala s lekcemi z vlastenectví. Podle obecné představy měl každý pouze jeden národní stát a podmínkou života na zemi bylo osvojení národní identity. Společenské vědy tento předpoklad nezkoumaly ani neproblematizovaly, naopak, zcela samozřjejmě z něj vyvozovaly konceptualizace, jimiž jsme se podrobně zabývali v předcházející části. 
Alespoň stručným připomenutím kontextu studené války, v němž sociální vědy dosáhly zralosti, můžeme získat další vhled do způsobu, kterým toto prostředí ovlivňovalo migrační studia. V Evropě soupeření se Sovětským svazem povzbudilo rozvoj sociálnědemokratických ideologií a jisté verze kapitalismu sociálního blaha. Lid ted' nepředstavoval pouze národ, společenství občanů a svrchovaných, ale také skupinu solidarity. Ustavením národních sociálních států dosáhl nacionalistický projekt svého vrcholu a naplnění. Př́íslušnost k této skupině solidarity byla privilegiem, a státní hranice vyznačovaly omezení př́stupu $\mathrm{k}$ těmto privilegiím (Wimmer 1998a).

Navíc napětí a nedůvěra studené války si žádaly stále přísnější dohled nad hranicemi a důkladné prošetřování motivů těch, kdo se státní hranice pokoušeli překročit. Imigrace se stávala stále složitější. Pro překročení železné opony se člověk musel stát politickým uprchlíkem. Na Západě se právo na přesun a opětovné usazení přiznávalo pouze těm, kdo utekli před komunismem. Jinak panoval konsenzus, že státní hranice by měly omezovat proudění obyvatelstva a sloužit jako nádoby, v nichž budou národní kultury přechovávány a kultivovány. Avšak po konci války se obnovily průmyslové struktury a to spolu s vylidněním starého kontinentu následkem recese a válek vyvolalo novou poptávku po pracovní síle v západní Evropě a USA.

V této konjunktuře se Anglie, Francie a Nizozemsko obrátily na své vlastní koloniální populace, tedy na populace vzdělávané tak, aby v koloniální mocnosti viděly mateřskou zemi a aby s ní sdílely jazyk a vzdělávací systém. Západní Německo se snažilo příliv pracovníků omezit a kontrolovat užíváním pracovních smluv pro nábor gastarbeiterů. Pováleční západoněmečtí vůdcové, tváří v tvář soupeři v podobě socialistického východního Německa, narazili na mimořádně naléhavou nutnost dosáhnout národního konsenzu a pracovního smíru pomocí štědrých sociálních dávek pro občany. Gastarbeiteři se jevili jako vhodné řešení poptávky po tvárné pracovní síle pro potřeby poválečné rekonstrukce a průmyslového rozvoje, protože nabízeli svou práci a současně nenarušovali kulturní ani ekonomickou smlouvu, kterou se se svými občany snažili němečtí lídři uzavřít. USA užívaly po troše z obou strategií - mobilizovaly obyvatelstvo své kolonie Portoriko a vyvinuly také pracovní program - tzv. Bracero Program - pro mexické námezdní dělníky. Tyto strategie, ačkoli zdánlivě velice odlišné, uspokojovaly potřeby průmyslu a současně minimalizovaly výzvy když ne pro praxi, tak alespoň pro koncepci národní izolace, kterou společenská věda naturalizovala a normalizovala.

I přes masivní asimilační snahy si v USA předchozí vlny imigrantů usazených v městských oblastech uchovaly své národní identity, i když kulturními praktikami se imigranti stále více přibližovali svým sousedům, př́islušníkům dělnické třídy (Gans 1982). Obecná mluva označovala tyto skupiny jako „národnosti“ (nationalities), čímž odrážela předválečné ideologie př́slušnosti k národu. Existují jisté doklady toho, že rodiny a organizace v rámci těchto národnostních skupin začaly obnovovat transnacionální spojení přerušená dvěma světovými válkami. Politici, kteří vedli kampaně v přistěhovaleckých čtvrtích, si těchto vazeb všímali a slibovali v americké zahraniční politice rozvíjet a podporovat pomoc pro vlast kterékoliv národnostní skupiny, již oslovovali - Irů, Italů, Poláků, Srbů či Řeků (Glick Schiller 1999a, 1999b; Redding 1958; Weed 1973). Ale zásluhou omezení, která na společenské vědy uvalil model společnosti jako nádoby, zůstává velká část této historie dosud neodhalena. V USA sociální vědy až do klíčové výzvy Glazera a Moynihana (1963) k posunu „za tavící kotlík“ 
přehlížely tyto přetrvávající identity a také způsob organizace politického života $\mathrm{v}$ amerických městech, který spíš přisuzoval význam soupeřícím etnickým skupinám, než reagoval na třídní diskurz (cf. Steinberg 1989). Místo toho zobrazovaly přistěhovalce jako vykořeněné ze svých mateřských zemí a věnovaly mnoho času a zdrojů měření tempa a míry asimilace.

V 60. letech 20. století se značná část této rétoriky v USA náhle změnila a dopady těchto změn na rétoriku budování národního státu a na společenské vědy rezonovaly po celém světě, zejména po konci studené války. Katalyzátorem těchto změn se stalo americké hnutí za občanská práva, které demaskovalo nevyřčené, ale institucionalizované ztotožnění americké identity s bílou barvou pleti. Černí aktivisté se ve snaze vytvořit pro sebe odlišenou a protestní politickou identitu vrátili zpět k předválečnému panafrickému hnutí a oživili afroamerickou kulturní politiku (Ture a Hamilton 1992/1967). Inspirovány hnutím Černá síla (Black Power) začaly i další skupiny obyvatel, které byly z amerického rasizovaného projektu budování národa $\mathrm{s}$ jeho normativním bělošstvím vyloučeny, vypracovávat ideologie kulturního pluralismu (Glazer a Moynihan 1963; Glick Schiller 1975, 1977; Steinberg 1989). V tomto kontextu, kde mělo odhalení amerického rasismu implikace i pro studenou válku, byly rasově konstruované národní kvóty z amerických imigračních zákonů v roce 1965 konečně odstraněny.

Podívejme se ted’ na Evropu. V Západním Německu se poválečný projekt rekonstrukce národního státu snažil obnovit národní kulturu a současně zapudit nacistickou ideologii. Lid byl nadále primárně definován jako národ se sdílenou kulturou a dějinami, nyní včetně hrůz nacistického období a historické odpovědnosti, které z nich plynuly a které se staly hlavním prvkem kolektivního vědomí vzdělaných elit. Soudobí sociální vědci toto pojetí německého lidu coby ustaveného společným dějinným osudem a kulturou nezpochybňovali a přijali názor, že cizinci se mohli stát Němci pouze velmi obtížně, ačkoliv údaje o historii Německa jasně ukazovaly rozšířenou absorpci imigrantů před první světovou válkou.

Jelikož se v souladu s tímto konceptuálním rozdělením na domorodce a cizáky očekávalo, že se přistěhovalečtí pracovníci vrátí domů, zpočátku nepředstavovali téma společenskovědného výzkumu nebo teorie. Avšak když se ukázalo, že se mnozí z nich v Německu usadili a začlenili, němečtí výzkumníci začali zjištovat jejich počty a vliv. Zajímali se zejména o následky pro národní třídní systém, přesněji řečeno o způsob, jímž nově vnesené prvky kastovní stratifikace oddělovaly imigranty-cizince od národního obyvatelstva (viz průkopnickou práci Castlese a Kosacka 1974, nebo z funkcionalistického pohledu HoffmannNowotny 1973). Odlišnost přistěhovalců a vazby na domov se braly jako dané. Kontrast s USA je působivý a potvrzuje naši hypotézu o ovlivnění vědy konkrétními zkušenostmi formace národního státu: němečtí vědci nevypracovali modely ani měřítka nevyhnutelné asimilace a politického začlenění srovnatelná s americkou sociologií, která v poválečných letech produkovala nejprve stále jemnější měřítka a stupnice asimilace a poté modely kulturního pluralismu.

Uprostřed začleňování přistěhovalců, kteří byli definováni sice jako černí, ale Briti, se britští sociální vědci pro účely popisu a problematizace migrantů uchýlili k teoriím rasových vztahů, jež odrážely důležitost rasových kategorií pro britskou zkušenost budování národa v kontextu jeho imperiální expanze. Tak jako jinde, i zde omezený pohled na národ a ona ideologie, podle níž k teritoriím přináleží navzájem odlišné národní kultury, vylučovaly výzkum 
přetrvávajících vazeb bývalých obyvatel kolonií na domov. Ve stejném období pomohly transnacionální populace z Indie, Pákistánu, Karibiku a Afriky Britům udržet si ve svých bývalých koloniích vliv $\mathrm{v}$ době, kdy se rozvinulo soupeření o politickou hegemonii a př́stup k surovinám jak se Sovětským svazem, tak se Spojenými státy. Nicméně metodologický nacionalismus vylučoval post-koloniální vědu, která by zkoumala kontinuitu říše během éry formální suverenity.

Francouzští učenci připomínali své kolegy z jiných států tím, že přijímali pohled vlastního státu na vztahy mezi národem a společenstvími občanů a svrchovaných (Silverman 1995). Francouzský lid viděli primárně jako politickou pospolitost, kterou spojoval demokratický proces, akt sebe-ustavení, který proměňuje občany na členy národa, abychom parafrázovali slavnou Renanovou formulaci. $V$ důsledku toho jsou přistěhovalci politicky začleňováni udělením státního občanství, jež implikuje a předpokládá kulturní asimilaci, získání př́islušnosti k francouzskému národu. Politické začleňování a kulturní asimilace zaručují, že skvrny cizosti získají co nejrychleji barvy trikolóry.

Na základě této filozofie integrace antropologové odmítli zavést odvětví pro studium přistěhovalectví, protože nechtěli stavět kulturní bariéry mezi novými a starými občany „Velkého Národa“ (Meillassoux 1980). Byli to sociologové, kdo poskytli reflexi a zároveň zdůvodnění integrace à la française popisem toho, jak udělování občanství a politická inkorporace vytvoří prostřednictvím identifikace a sociálního míšení novou skupinu skutečných Francouzů (toto je kanonická pozice formulována in Schnapper 1991). I kdyby byli společenští vědci chtěli, čelili by při popisování a zdůrazňování rozdílů mezi novými a starými Francouzi ohromným obtížím. Národní systémy sčítání lidu nerozlišují mezi nově přijatými občany a français de souche ${ }^{8}$. Studie Michèle Tribalat (1995) o asimilaci imigrantů založená na datech, která se tohoto dělení držela, vyvolala skandál i přesto, že její výsledky k veliké úlevě politiků i akademiků potvrzovaly, že francouzský asimilacionismus funguje a účinně mění prristěhovalce na Francouze.

Stručně řečeno, na vrcholu studené války a moci nacionalizovaných států jednotlivé konkrétní styly budování národa vedly také - skrze zrcadlové efekty metodologického nacionalismu - k různým typům společenskovědného uvažování o imigraci. Každý, kdo sledoval obtíže provázející nadnárodní komunikaci na konferencích, nemluvě o spolupráci na společných výzkumných projektech, vnímal toto vzájemné odcizení a někdy dokonce i uvádění v úžas (o vztahu mezi styly budování národa a filozofiemi integrace přistěhovalců viz také Brubaker 1992, Castles 1995, Favell 1998).

8 Z francouzštiny (správně psáno coby etnonymum s velkým „F“) doslova „Francouzi s kořeny“, ve volnějším překladu původní, domorodí Francouzi, kteří se stejně jako jejich předkové narodili ve Francii. Nejedná se o termín užívaný francouzskými vládními orgány či legislativou, ale spíše o potenciálně kontroverzní výraz obecné mluvy, asociovaný mimo jiné s rétorikou Národní fronty (Front national) (pozn. překl.). 


\section{Za hranice metodologického nacionalismu?}

Současná éra globalizace proměnila migrační studia nástupem transnacionálního paradigmatu. Počátek ekonomické restrukturalizace současné globalizace se datuje do 70. let 20 . století, kdy došlo $\mathrm{k}$ pádu dohody z Bretton Woods, $\mathrm{k}$ přesunu průmyslové výroby z USA a Evropy na místa s nižšími pracovními náklady a k rozvoji nových způsobů rízení a uspíšení rychlého toku kapitálu.

Celosvětová recese a ropná krize 70 . let, které snad vyvolaly novou etapu globalizace, podnítily po celé Evropě hnutí proti přistěhovalcům a nastolily konsenzus, že imigrace musí být zásadně omezena či zcela zastavena. Touto dobou se obviňování cizinců z čehokoliv stalo pro domácí občany akceptovanou reakcí i přesto, že samotná identifikace územně vymezené populace s národním státem (a to pouze $\mathrm{s}$ jediným národním státem) byla relativně novým vynálezem. Tendence brzdit migraci jako řešení problémů, které byly ve skutečnosti systémové povahy, nabývala na různých místech různou formu a v průběhu 20 let její stále př́isnější realizace omezila práva obyvatel bývalých kolonií na občanství a náhle ukončila programy pro sezónní zahraniční dělníky. Rétorika nulové imigrace zakrývala fakt, že dveře zůstaly otevřené pro pokračující imigraci rodinných př́slušníků, vysoce kvalifikovaných přistěhovalců a osob klasifikovaných jako političtí uprchlíci. Ve skutečnosti rychlé globalizační tempo, jež ještě zvýšila implementace hospodářských reforem v Rusku a východní Evropě po konci studené války a v Asii po asijské ekonomické krizi v 90. letech 20. století, tempo migrace urychlilo. Migrace je nyní strukturována, vnímána a zkoumána na různých místech v rámci různých kategorií: toky uprchlíků, opětovné spojení rodin, nábor kvalifikovaných pracovníků skrze zvláštní víza, domácí námezdní pracovní síla a ilegální přistěhovalci.

Společenskovědné teorie migrace se zásadně nezměnily, dokud neskončila studená válka a podobně jako Berlínská zed' nepadly některé př̌kážky metodologického nacionalismu. Odborníci v mnoha oblastech společně s politickými vůdci a novináři začali ohlašovat, že se svět stává kvalitativně odlišným, a fascinováni různými druhy toků lidí, myšlenek, předmětů a kapitálu skrz územní hranice států označili to, co pozorovali, termínem „globalizace“.

$\mathrm{V}$ antropologii vedla globalizační horečka k procesu, jejž bychom mohli nazvat „rozcupováni““ (dissing) předchozích paradigmat. Slyšíme o rozdělování (disjuncture), roz-místování (dislocation), vymístování (displacement), rozvolňování (disengagement), rozpojování (disconnection) a rozebírání (dismantling) starých stabilit, poznatků, konvencí a identit (Appadurai 1990, 1991, 1993; Featherstone 1993; Rouse 1991). Antropologové a etnograficky zaměření sociologové, pracující nezávisle na sobě na východním a západním pobřeží USA, začali postulovat nástup nového druhu migrace, který pojmenovali transnacionalismus (Glick Schiller a Fouron 1991, Glick Schiller et al. 1992, Goldring 1996, Guarnizo 1997, Kearney 1991, Levitt 1997, Rouse 1992). Později se k tomuto trendu přidal i hlavní proud sociologie a důrazně se podílel na jeho formulaci a rozš́irení (Portes et al. 1999). Nová data popisující transnacionální vazby soudobých migrantů byla představena dokonce ještě předtím, než se antropologové a sociologové začali $\mathrm{k}$ transnacionální migraci vyjadřovat, ale metodologický nacionalismus zabránil vědcům plně docenit a teoreticky uchopit, co viděli (Chaney 1979, Gonzalez 1988).

První vlna globálních studií přinesla řadu problematických předpokladů. Za prvé vědci inklinovali k pohledu na komunikační technologie (počítače, telefony, televizi, komunikační 
satelity a další elektronické inovace) jako na motor změn. Najednou jsme všichni mohli vizuálně zakoušet stejnou válku, stejný koncert nebo stejnou reklamu a podílet se na informačním věku. Moc této nové technologie $\mathrm{v}$ kombinaci s postmoderním zdůrazňováním stálosti minulosti a tekutosti prŕtomnosti vedly $\mathrm{k}$ dosti hrubému technologickému determinismu, který zvláštně protiřečil jinak konstruktivistickému zaměření velké části této literatury. To zabránilo diskusi o širších minulých a současných sociálních a ekonomických sílách, jež formovaly transnacionální vazby propojující celou planetu. Navíc dopad dř́iějších technologií, které ulehčily předchozí skoky v globální integraci, včetně parolodi, telegrafu, telefonu a rozhlasu, byl přezírán anebo zapomenut.

Za druhé první vlna transnacionálních studí́ měla sklon mluvit o globalizaci ve smyslu epochálního obratu, přičemž předchozí historické období charakterizovala jako dobu, v níž byly naše analytické jednotky jasně ohraničené a v níž žili lidé $\mathrm{v}$ těchto ohraničených jednotkách kmene, etnické skupiny a státu. Mnozí vědci tvrdili, že zvýšený přeshraniční pohyb signalizoval zánik národního státu jakožto mocenského centra a taktéž jako vlivného zdroje politiky identity (Kearney 1991). Minulost byla statická, př́tomnost byla tekutá; minulost obývaly homogenní kultury, zatímco nyní jsme žili ve světě hybridity a komplexity.

Objevila se druhá vlna globálních studií, která koriguje část chybných pojetí z několika prvních let. Zmíníme se o pěti momentech tohoto přechodu. Za prvé ted' dokážeme přiznat, že globalizace není sama o sobě novým fenoménem (Went 2000, Wimmer 2001a). Náš článek vysvětlil, že spolu s významnými změnami, jež se od konce studené války ve světě odehrály, prožíváme také změnu paradigmatu. Začali jsme být schopni analyzovat transnacionální migraci a nacionalismus na dálku a debatovat o nich, protože jsme změnili čočky, přes které vnímáme a analyzujeme svět, a odložili stranou některé z předsudků metodologického nacionalismu.

Tento nový, sofistikovanější směr bádání, který vznáší otázky o skutečné povaze nové globalizace a transnacionalismu, rozplétá dlouhodobé trendy a periodicky se opakující i nově se vyskytující jevy v historickém vývoji globálních propojení (Glick Schiller 1999a, 1999b, 1999c; Panitch 1996, 2000; Smith 1997; Went 2000; Wilson a Donnan 1998). Ve skutečnosti byla planeta již od počátku evropské expanze v 15. století zapojena do různých druhů ekonomických aktivit a toků předmětů a idejí. Kolonizace byla globálním procesem, který splétal nesourodá území a populace. Někteř́ autoři začali tvrdit, že svět byl vlastně více globálně integrovaný v 19. století, než je nyní, anebo že až v současnosti se vracíme $\mathrm{k}$ tomu druhu integrace, který svět prožíval před první světovou válkou (viz shrnutí této diskuse in Jessop 1999). Existuje nicméně všeobecná shoda, že soudobé globalizační procesy se zdají být silnější svým stupněm proniknutí do rytmu každodenního života po celém světě (Held et al. 1999).

Na poli migračních studií se po počátečních oslavách novosti diasporických identit začalo formovat opatrnější zkoumání historického rozměru diasporických zkušeností (Cohen 1997; Foner 1997, 2001; Morawska 2001). To nám dovoluje zhodnotit transnacionální praktiky, z nichž vzešly kultury, jež nacházíme například v karibské oblasti nebo v post-koloniálních společnostech od Indie po Samou.

Za druhé vědci z Asie i Latinské Ameriky začali zkoumat zapojení regionů do globálních procesů, čímž překonávali další omezení metodologického nacionalismu a prolamovali 
národní zaostření paradigmat rozvoje a modernizace. Významnou roli při zkoumání místních a regionálních variací ve spojení globálního a lokálního hrají antropologové. Ti také prrinesli popisy asijských diskursů „alternativních modernit“ a probádali specifika transnacionálních procesů v Č́ně a jihovýchodní Asii (Ong 1997, Ong a Nonini 1997, Smart 1997, Szanton Blanc 1997). Obraz jednosměrné cesty dějin a globalizace - dědictví schémat velké sociální teorie - je tudíž pomalu překonáván uznáním vícerých cest vedoucích $\mathrm{k}$ modernitě a jejímu překonání (Eisenstadt 2000, Therborn 1995, Wimmer 2001b).

Za třetí mnohem více pozornosti se nyní věnuje přetrvávající úloze národního státu v transnacionálních procesech. Stále zjevněji se ukazuje, že národní stát „byl poněkud úspěšnější při odolávání bouřím post-socialismu, post-kolonialismu a globalizace“, než tomu bylo v době raných výzkumů globalizace (Panitch 2000; Sassen 1996, 2001). Autoři si rovněž začali všímat minulé a současné role národních států při živení přetrvávajících vazeb s populacemi usazenými v cizině, čímž relativizovali dřívější prohlášení o „úpadku národního státu“ (Basch et al. 1994; Glick Schiller 1999a, 1999b, 1999c; Guarnizo 1997, 1998; Guarnizo a Diaz 1999; Mahler 1998; R. Smith 1998; Smith a Guarnizo 1998).

A nakonec byl rozvinut pojem nacionalismu na dálku, který znovu oprašuje ,vlastenecký“ nacionalismus, jenž pozorovali, avšak nepojmenovali a neprozkoumali odborníci na nacionalismus a chicagská škola (Anderson 1993, 1994; Fuglerud 1999; Glazer 1954; Skrbiš 1999). Nacionalismus na dálku navzájem spojuje lidi, kteří žijí v různých geografických prostorech, a motivuje je, aby jednali ve vztahu k území svých předků a jeho vládě. Pomocí těchto ideologických spojení se teritorium, jeho lid a jeho vláda stávají přeshraniční iniciativou. Dálkový nacionalismus může slučovat přistěhovalce, jejich potomky a lidi, kteří zůstali ve své vlasti, do křehkého, ale nepřehlédnutelného přeshraničního společenství občanů (Glick Schiller a Fouron 2001a: 17-20). Podobně jako u jiných verzí nacionalismu, pojem lidu zahrnující občany, svrchované osoby a př́islušníky národa a skupiny solidarity zůstává významný, ale tato jednotlivá vtělení nejsou chápána jako totožná a teritoriálně omezená.

Množství otázek týkajících se transnacionální migrace a dálkového nacionalismu, jež nemohlo být vzneseno během předchozích období, nyní tedy může být zkoumáno a teoretizováno. Avšak neznamená to, že jsme se osvobodili od vlivu metodologického nacionalismu. Nadále usilujeme o porozumění tomu, jak naše umístění v mřížce národních států a omezení, která z něj vyplývají pro naši vědeckou perspektivu, formují a deformují náš pohled. Uzavíráme tuto část přehledem některých oblastí, v nichž je metodologický nacionalismus stále viditelný.

Diasporická studia často sledují rozptýlené populace bez ohledu na to, kde se usadily, a soustředí se na dynamiku vzájemného propojení, nostalgii, pamět' a identitu konkrétní populace, kterou usouvztažňují s konkrétní vlastí. Národ sice již není uzavřen v územně omezené entitě a rozprostírá se přes různá území a místa, přesto vládne jeho představa jako organického a integrovaného celku. Tento modus operandi obvykle přehlíží procesy budování národního státu, které se dotýkají diasporických populací na různých místech. Je-li vztah mezi diasporou a budováním národního státu zkoumán, pak jedině a výhradně ve smyslu př́slušné diasporické vlasti a její politiky. Dochází tudíž k reprodukci obrazu a analytických technik spojených s popisem ohraničené národní společnosti jako nádoby, jakkoli v jiné podobě. 
Podobné poznámky je na místě vztáhnout i na výzkum „transnacionálních komunit“. Platí zde četná kritika minulých omylů studií komunit: značná část transnacionálních výzkumů nadsazuje vnitřní stejnorodost a ohraničenost transnacionálních komunit, přeceňuje jejich závaznost pro jednání jednotlivců, přehlíží důležitost interakcí mezi jednotlivými komunitami a také vnitřní dělby podle třídy, genderu, náboženství a politického přesvědčení, a nakonec je konceptuálně slepá vůči př́ípadům, kdy se mezi migranty netvoří žádné transnacionální komunity nebo kdy ty existující ztrácejí pro jedince smysl. Navíc předem vylučuje možnost různých významů konkrétní transnacionální identity - významů, které navádějí aktéry do velice rozmanitých politických směrů a spojenectví. Stručně řečeno, př́stup k transnacionálním sociálním polím a sítím migrantů jako k pospolitostem inklinuje k reifikaci a esencializaci komunit podobným způsobem, jakým předchozí př́stupy reifikovaly národní pospolitosti nebo jakým Redfieldova škola esencializovala rolnické komunity.

Neo-komunitarismus transnacionálních studií dosti překvapivě reprodukuje standardní obraz světa rozděleného na národy, a tím v jiných formách tento pohled na svět naturalizuje. Transnacionální nás sémanticky odkazuje $\mathrm{k}$ ne-transnacionálnímu nebo jednoduše nacionálnímu jako entitě, která je překlenována či nahrazována. Migranti již nejsou vykořeněni ani nešplhají po žebříku asimilace do národní stř̌ední třídy, ale stále představují ty jiné, odlišné a cizí pro národně ohraničenou společnost. Studie, které zkoumají spojení mezi transnacionálními migranty a aktéry na různých místech, v nichž se usazují a na něž se stěhují, nás mohou přenést za statický, reifikovaný a esencializovaný pojem komunity a umožnit výzkum migrantů a ne-migrantů v rámci sociálních polí diferencované moci (viz Nyiri 1999, Ong 1999, Wimmer 1998b).

\section{Několik závěrečných poznámek}

Překonání metodologického nacionalismu ve výzkumu soudobé migrace tudíž může vyžadovat více než jenom zaostření na transnacionální komunity místo na národ a jeho přistěhovalce. Abychom unikli z gravitačního pole zavedených metodologií, způsobů vymezení předmětu analýzy a algoritmů pro generování otázek, možná musíme vypracovat (nebo znovu objevit?) analytické nástroje a koncepty, jež nebudou zabarveny samozřejmostí světa sestávajícího $\mathrm{z}$ národních států. Toto je to, co společně s mnoha dalšími současnými pozorovateli společenských věd vnímáme jako klíčový úkol, jenž nás čeká. Zcela jistě nejsme schopni nabídnout takový soubor analytických nástrojů zde (Castles 2001, Wimmer 2002).

Jedním z cílů tohoto článku bylo spíše popsat, a to přesněji než doposud, překážky na této cestě k nové sociální teorii. Lepší znalost způsobu, jak v moderním světě projekt budování národního státu ovlivňoval naše vnímání migrace, včetně některých nedávných prací o transnacionalismu, představuje důležitý krok. Může nás ochránit před tím, abychom se v entuziastickém hledání nového rozběhli po nejslibněji vypadající cestě bez jasné představy, jak jsme se dostali na křižovatku, na níž se ve skutečnosti nacházíme. Pohled zpět nám může pomoci rozeznat stezky, které nás dovedou přesně tam, kde nyní stojíme. Popsali jsme tři mody metodologického nacionalismu, které formovaly společenskovědný program - přehlížení, naturalizaci a územní omezení - a identifikovali jsme způsoby, jimiž ovlivnily hlavní proud migračních studií. Popisováním imigrantů jako politických bezpečnostních hrozeb, 
jako kulturně odlišných, jako sociálně marginálních a jako výjimek z pravidla územního omezení migrační studia věrně odrážela nacionalistický obraz normálního života.

Naším druhým záměrem bylo načrtnout, nepochybně dosti odvážnými a rozmáchlými tahy, dějiny minulého století, což nám mělo pomoci pochopit, jak došlo k tomuto připoutání vědcova oka k tělu národa a jak se tento vztah vyvíjel v průběhu jednotlivých etap budování národa. Tento historický tour d'horizon jsme zahájili obdobím neomezené migrace v prostředí globalizované ekonomiky a zuřivého soupeření nacionalizujících se států, a ukončili jsme ho rovněž obdobím posilněné globalizace - naší současnou epochou. Mezi těmito dvěma etapami národní hranice stále více a více svazovaly tkanivo hospodářského, politického a kulturního života a model společnosti jako nádoby získal ve společenských vědách hegemonní postavení. Popsali jsme pro všechny tyto různé fáze, jak proces budování národního státu produkoval coby jeden ze svých aspektů i různé postoje vůči přeshraniční migraci a integraci přistěhovalců, které odrážely a někdy také udržovaly či dokonce vytvářely základní koncepty výzkumu migrace. Z tohoto historicky poučeného ,pohledu zdáli“ jsme měli možnost spatřit, co výzkumníci migrace viděli a co neviděli, a vysvětlit, proč tyto rozmanité slepé skvrny vznikly. Zaujali jsme úhel pohledu pozorovatele druhého řádu, který pozoruje, co profesionální pozorovatelé pozorují a nepozorují.

Pokusili jsme se proto dát př́klad, jak mohou být metodologická omezení pozorování prvního řádu překonána. Tento prríklad měl podobu antropologicky poučené historické narace. Takový př́stup neposkytuje dostatečně rozvinuté konceptuální nástroje, které by nám dovolily rozpracovat tuto perspektivu systematičtěji. To zůstává úkolem do budoucna. Nicméně na místě je malé varování. Bylo by určitě naivní domnívat se, že někdy rozvineme teoretický jazyk, který nebude hluboce ovlivněn sociálními a politickými silami kolem nás - většina z nás se již vzdala snu, že dosáhneme Archimédova pevného bodu, onoho bodu objektivity. Stejně naivní by bylo tvrdit, že metodologický nacionalismus bránil „skutečnému“ porozumění světu, jež je nyní třeba objevit. Časy, kdy platilo toto zrcadlové pojetí reality a vědeckého popisu, jsou také pryč.

I když stále usilujeme o adekvátní porozumění tomu, co se v současnosti děje, můžeme již předvídat, že nové koncepce, jež se časem objeví, znovu nevyhnutně omezí a ovlivní náš úhel pohledu a znovu nás přinutí přehlížet některé trendy a nadměrně zdůrazňovat jiné. Každá jasná konceptuální struktura nevyhnutně omezuje škálu možných interpretací, stejně jako empirické domény, jež mohou být smysluplně interpretovány. Rozumět znamená redukovat komplexitu. Avšak dostat se za tento truismus si vyžaduje určit, které redukce komplexity umožňují nejlépe pochopit současný svět a které vynechávají příliš mnoho tónů a hlasů, přičemž je proměňují v to, co budovatelé modelu nazývají „šum“. I když jsme jádro této stati věnovali popisu Charybdy metodologického nacionalismu, na závěr bychom rádi poukázali na Skyllu metodologického „fluidismu“.

K ní se zdá ubírat značná část současné teorie. Kde byly předtím neměnné hranice, tam je nyní všechno stejně a bezprostředně propojené. Struktury jsou nahrazeny tekutostí. Usazenost je nahrazena pohybem. Zatímco přistěhovalce bylo zvykem zobrazovat jako okrajovou výjimku z pravidla setrvání ve svém národním domově, dnes představuje transnacionální život migrantů v pohybu prototyp lidské situace. Územní omezenost analýzy nahradila spirálovitá rétorika deteritorializace a delokalizace. Zdá se, jako by soudobá sociální teorie, 
např́íklad práce Urryho (2000) či Papastergiadise (2000) ostře kritizované Favellem (2001), sotva dechu popadaje honila označující, která poháněna novými komunikačními technologiemi a globalizovanými trhy tryskají kolem planety.

Tito autoři mají sklon zapomínat, že výroba pro tyto trhy je zasazena do konkrétních geografických míst a probíhá $\mathrm{v}$ omezených, ne nevyhnutně teritoriálně ohraničených sociálních prostředích (Sassen 2001). Navíc i když je důležité odložit klapky metodologického nacionalismu, stejně tak důležité je pamatovat na přetrvávající sílu nacionalismu. Rámováním světa jako globálního tržiště se nedopátráme vysvětlení, proč za specifických okolností nejenom političtí podnikavci, ale taktéž chudí a bezmocní nadále rámují své požadavky sociální spravedlnosti a rovnosti nacionalistickou rétorikou a proč migranti někdy přijímají některý druh nacionalismu na dálku (Glick Schiller a Fouron 2001a, 2001b).

Dramatické prohlášení Stuarta Halla (1989), podle něhož ,jsme ted’ všichni migranti“, není v roce 2001 o nic pravdivější než v roce 1989, kdy vyzval k uvažování oproštěnému od protikladu občanů se stálými národními kulturami a migrantů s jejich spornými identitami. Nadále platí nejenom to, že 95 procent lidí na světě nejsou migranti, ale i to, že navzdory globálním médiím a rychlým informačním tokům zůstává na mnoha místech světa uchován význam národních identit.

Nemůžeme ani rozmarně zaujmout perspektivu kosmopolitismu, at' již coby popis postnacionálního stupně identity, nebo politický cíl hodný dosažení (Beck 2000). Takový postoj, který se ubírá cestou velice odlišnou od předchozích diskusí nad vynálezem či reprezentacemi komunity, může napomáhat dekonstrukci nacionalismu. Avšak není schopen obsáhnout skutečnost, že nacionalismus je mocným označujícím, které má nadále smysl pro různé hráče s různými úmysly a politickými implikacemi (Fouron a Glick Schiller v tisku; Friedman 1996; Glick Schiller a Fouron 2001a, 2001b). Na Skyllu fluidismu a rétoriky světoobčanství jsme poukázali - výzvou zůstává vypracovat pro výzkum migrace soubor konceptů, které dokážou více než pouze odrážet tyto předsudky a zdánlivě samozřejmé předpoklady naší doby.

Přeložil Marek Mikuš

\section{Poděkování}

Rádi bychom poděkovali organizátorům a účastníkům konference Rady pro sociálněvědný výzkum (Social Science Research Council, SSRC) o transnacionální migraci, která se konala na University of Princeton v červnu 2001 a na níž byla představena první verze tohoto článku. Naše zvláštní poděkování si zaslouží Stephen Castles a Aristide Zolberg za jejich podrobné a inspirativní rozbory tohoto článku, stejně jako Peter van der Veer, Rainer Bauböck, Werner Schiffauer, Robert Smith, Ewa Morawska a José Casanova za jejich poznámky a kritiky. Michael Bommes rukopis pročetl a poskytl podnětné poznámky, za které bychom mu rádi poděkovali. 


\section{Literatura}

ANDERSON, Benedict. The new world disorder. New Left Review, 1993, č. 193, s. 2-13. ISSN 0028-6060.

ANDERSON, Benedict. ,Exodus'. Critical Inquiry, 1994, č. 20, s. 314-327. ISSN 0093-1896.

APPADURAI, Arjun. Disjuncture and difference in the global cultural economy. Public Culture, 1990, č. 2, s. 1-24. ISSN 0899-2363.

APPADURAI, Arjun. Global ethnoscapes: notes and queries for a transnational anthropology. In FOX, R. (ed.) Recapturing anthropology. Santa Fe, NM: School of American Research Press, 1991, s. 191-211. ISBN 0-93345-278-0.

APPADURAI, Arjun. Patriotism and its futures. Public Culture, 1993, č. 5, s. 411-429. ISSN 0899-2363.

BASCH, Linda; GLICK-SCHILLER, Nina; SZANTON-BLANC, Cristina. Nations unbound: transnational projects, postcolonial predicaments and deterritorialized nation-states. 1. vyd. Amsterdam: Gordon and Breach, 1994. 360 s. ISBN 2-88124-630-3.

BECK, Ulrich. The cosmopolitan perspective: sociology of the second age of modernity. British Journal of Sociology, 2000, č. 51, s. 79-105. ISSN 0007-1315.

BENDER, Thomas. Writing national history in a Global Age. Correspondence: an international review of culture and society, 2001, č. 7 .

BERLIN, Isaiah. Nationalism: past neglect, present power. In HARDY, H., HAUSHEER, R. (eds.) The proper study of mankind: an anthology of essays. London: Pimlico, 1998, s. 581-604. ISBN 0-37423-750-6.

BILLIG, Michael. Banal nationalism. 1. vyd. London: Sage, 1995. 208 s. ISBN 0-80397-525-2. BOLZMAN Claudio; FIBBI, Rosita; VAIL, Marie. Adultes issus de la migration: le procesus d'insertion d'une generation á l'autre', Rapport de recherche au PNR39. Geneve: Institut d'études socials, manuscript, 2000.

BOMMES, Michael; HALFMANN, Jost. Migration und Inklusion: Spannungen zwischen Nationalstaat und Wohlfahrtsstaat. Kölner Zeitschrift für Soziologie und Sozialpsychologie, 1994, č. 46, s. 406-424. ISSN 0023-2653.

BORNEMAN, John. State, territory, and national identity formation in the two Berlins, 1945-1995. In GUPTA, A., FERGUSON, J. (eds.) Culture, power and place: explorations in critical anthropology. Durham, NC: Duke University Press, 1997, s. 93-117. ISBN 0-82231-940-3.

BREUILLY, John. Nationalism and the state. 1. vyd. Manchester: Manchester University Press, 1994. 474 s. ISBN 0-22607-414-5.

BRUBAKER, Rogers. Citizenship and nationhood in France and Germany. Harvard: Harvard University Press, 1992. $288 \mathrm{~s}$.

BRUBAKER, Rogers. Myths and misconceptions in the study of nationalism. In HALL, J. (eds.) The state of the nation: Ernest Gellner and the theory of nationalism. Cambridge: Cambridge University Press, 1998, s. 272-306. ISBN 0-52163-324-9.

CALHOUN, Craig. Nationalism. Minneapolis: University of Minnesota Press, 1997. 164 s. ISBN 0-81663-121-2. 
CASTLES, Stephen. How nation-states respond to immigration and ethnic diversity. New Community, 1995, č. 21, s. 293-308. ISSN 0047-9586.

CASTLES, Stephen. Studying social transformation. International Political Science Review. 2001, č. 22, s. 13-32. ISSN 0192-5121.

CASTLES, Stephen; KOSACK, Godula. Immigrant workers and class structure in western Europe. London: Oxford University Press, 1974. 528 s. ISBN 0-19218-197-1.

CHANEY, Elsa. The world economy and contemporary migration. International Migration Review, 1979, č. 13, s. 204-212. ISSN 0197-9183.

CINEL, Dino. From Italy to San Francisco: the immigrant experience. Stanford, CA: Stanford University Press, 1982. 347 s. ISBN 0-80471-117-8.

COHEN, Robin. Global diasporas: an introduction. Seattle: University of Washington Press, 1997. 224 s. ISBN 0-29597-620-9.

DIKÖTTER, Frank. Racial discourse in China: continuities and permutations. In DIKÖTTER, F. (eds.) The construction of racial identities in China and Japan: historical and contemporary perspectives. Honolulu: University of Hawaii Press, 1997, s. 12-33. ISBN 0-82481-919-5.

EISENSTADT, Shmuel N. Multiple modernities. Daedalus: Journal of the American Academy of Arts and Sciences, 2000, č. 129, s. 1-29. ISSN 0011-5266.

ESSER, Hartmut. Ethnische Differenzierung und moderne Gesellschaft. Zeitschrift für Soziologie, 1988, č. 17, s. 235-248. ISSN 0340-1804.

FAVELL, Adrian. Philosophies of integration: immigration and the idea of citizenship in France and Britain. London: Macmillan, 1998. 304 s. ISBN 0-31217-609-9.

FAVELL, Adrian. Review essay: Migration, mobility and globaloney: metaphors and rhetoric in the sociology of globalization. Global Networks, 2001, č. 1, s. 389-398. ISSN 1470-2266.

FAVELL, Adrian. The integration of immigrants in Western Europe: contours and constraints of a research paradigm. In BOMMES, M., MORAWSKA, E. (eds.) Reflections on migration research: constructions, omissions and promises ofinterdisciplinarity. Berkeley: University of California Press. [forthcoming].

FEATHERSTONE, Mike. (eds.) Global culture: nationalism, globalization and modernity. 1. vyd. London: Sage, 1990. 411 s. ISBN 0-80398-322-0.

FONER, Nancy. What's new about transnationalism? New York immigrants today and at the turn of the century. Diaspora. 1997, č. 6, s. 355-374.

FONER, Nancy. (eds.) Islands in the city: West Indian migration to New York. 1. vyd. Berkeley: University of California Press, 2001. 320 s. ISBN 0-52022-850-2.

FOURON, Georges; GLICK-SCHILLER, Nina. Killing me softly: violence, globalization and the apparent state. In FRIEDMAN, J. (eds.) Globalization, the state and violence. Lanham, MD: AltaMira Press. [forthcoming].

FRIEDMAN, Jonathan. Politics of de-authentification: escaping from identity, a commentary on ,beyond authenticity“ by Mark Rogers. Identities, 1996, č. 3, s. 127-136.

FUGLERUD, Oivind. Life on the outside: the Tamil diaspora and long distance nationalism. London: Pluto, 1999. 224 s. ISBN 0-74531-433-3. 
GABACCIA, Donna R. Italy's many diasporas: elites, exiles and workers of the world. 1. vyd. Seattle: University of Washington Press, 2000. 280 s. ISBN 1-85728-582-4.

GANS, Herbert. The urban villagers: group and class in the life of Italian-Americans. 2. vyd. New York: Free Press, 1982. 443 s. ISBN 0-02911-240-0.

GELLNER, E. Nations and nationalism. Ithaca: Cornell University Press, 1983. 150 s. ISBN 0-80149-263-7.

GIDDENS, Anthony. Nation-state and violence. Los Angeles: University of California Press, 1995.

GILROY, Paul. There ain't no black in the Union Jack: the cultural politics of race and Nation. Chicago: University of Chicago Press, 1991. 280 s. ISBN 0-22629-427-7.

GILROY, Paul. The black Atlantic: modernity and double consciousness. Cambridge MA: Harvard University Press, 1993. 320 s. ISBN 0-86091-675-8.

GLAZER, Nathan. Ethnic groups in America: from national culture to ideology. In BERGER, M. ABEL, T., PAGE, C. (eds.) Freedom and control in modern society. New York: Van Nostrand, 1954, s. 158-173.

GLAZER, Nathan; MOYNIHAN, Daniel P. Beyond the melting pot: the Negroes, Puerto Ricans, Jews, Italians, and Irish of New York City. Cambridge, MA: MIT Press, 1963.

GLICK (SCHILLER) BARNETT, Nina. The formation of a Haitian ethnic group. [Ph.D. dissertation]. New York: Department of Anthropology, Columbia University, 1975.

GLICK-SCHILLER, Nina. Ethnic groups are made not born. In HICKS, G. L., LEIS, P. E. (eds.) Ethnic encounters: identities and contexts. North Scituate, MA: Duxbury Press, 1977, s. 23-35. ISBN 0-87872-135-5.

GLICK-SCHILLER, Nina. Transmigrants and nation-states: something old and something new in US immigrant experience. In HIRSCHMAN, C., DeWIND, J., KASINITZ, P. (eds.) Handbook of international migration: the American experience. New York: Russell Sage, 1999, s. 94-119. ISBN 0-87154-244-7.

GLICK-SCHILLER, Nina. Who are these guys? A transnational perspective on national Identities. In GOLDIN, L. (eds.) Identities on the move: transnational processes in North America and the Caribbean Basin. Houston: University of Texas Press, 1999, s. 15-44. ISBN 0-94204-118-6.

GLICK-SCHILLER, Nina. Transnational nation-states and their citizens: the Asian experience. In OLDS, K., DICKEN, P., KELLY, P., KONG, L., WAI-CHUNG YEUNG, H. (eds.) Globalization and the Asia Pacific. London: Routledge, 1999, s. 202-218.

GLICK-SCHILLER, Nina. Long distance nationalism: pasts, presents, and futures, paper delivered at Harvard Anthropology Seminar. 2000.

GLICK-SCHILLER, Nina; FOURON, Georges. Everywhere we go we are in danger: Ti manno and the emergence of a Haitian transnational identity. American Ethnologist, 1991, č. 17, s. 329-417. ISSN 0094-0496.

GLICK-SCHILLER, Nina; FOURON, Georges. Georges woke up laughing: long distance nationalism and the search for home. Durham, NC: Duke University Press, 2001. 352 s. ISBN 0-82232-791-0.

GLICK-SCHILLER, Nina; FOURON, Georges. I' am not a problem without a solution: poverty, transnational migration, and struggle. In MASKOVSKY, J., GOOD, J. (eds.) 
New poverty studies: the ethnography of power, politics and impoverished people in the US. New York: New York University Press, 2001, 321-363. ISBN 0-81473-116-3.

GLICK-SCHILLER, Nina; BASCH, Linda; BLANC-SZANTON, Cristina. Towards a transnational perspective on migration: race, class, ethnicity and nationalism reconsidered. New York: New York Academy of Sciences, 1992. 276 s.

GLICK-SCHILLER, Nina; BASCH, Linda; BLANC-SZANTON, Cristina. From immigrant to transmigrant: theorizing transnational migration. Anthropology Quarterly, 1995, roč. 68, S. $48-63$.

GOLDRING, Luin. Blurring borders: constructing transnational commumty in the process of Mexico-US migration. Research in Community Sociology, 1996 č. 6, s. 69-104. ISSN 1058-5028.

GONZALEZ, Nancie L. Soujourners of the Caribbean: ethnogenesis and ethnohistory of the Garifuna. Urbana: University of Illinois Press, 1988.

GUAMIZO, Luis E. The emergence of a transnational social formation and the mirage of return migration among Dominican transmigrants. Identities, 1997, č. 4, s. 281-322.

GUAMIZO, Luis E. The rise of transnational social formations: Mexican and Dominican state responses to transnational migration. Political Power and Social Theory, 1998, č. 12, s. 45-94. ISSN 0198-8719.

GUAMIZO, Luis E.; DIAZ, Luz M. Transnational migration: a view from Colombia. Ethnic and Racial Studies, 1999, č. 22, s. 397-421. ISSN 0141-9870.

GUERNÉE, Bernard. Des limites féodales aux frontiěres politiques. In ORA, P. (eds) Les lieux de Memoire. La Nation, Vol. 2. Paris: Gallimard, 1986, s. 11-34.

GUIBERNAU, Montserrat. Marx and Durkheim on nationalism. In WICKER, H. R. (eds.) Rethinking nationalism and ethnicity: the struggle for meaning and order in Europe. Oxford: Berg, 1997, s. 73-90. ISBN 1-85973-931-8.

HALL, Catherine; McCLELLAND, Keith; RENDALL, Jane Defining the Victorian nation: class, race, gender and the British Reform Act of 1867. Cambridge: Cambridge University Press, 2000, 320 s. ISBN 0-52157-653-9.

HALL, Stuart. Ethnicity, identity and difference. Radical America, 1989, č. 23, s. 9-20. ISSN 0033-7617.

HARRINGTON, Mona. Loyalties: dual and divided. In THEMSTROM, s. (eds.) The politics of Ethnicity. Cambridge, MA: Belknap Press, 1982, s. 104-109.

HELD, David; McGREW, Anthony; GOLDBLATT, David; PERRATON, Jonathan. Global transformations: politics, economics and culture. 1. vyd. Oxford: Polity Press, 1999. 540 s. ISBN 0-80473-627-8.

HENKE, Roger. Funding possibilities for ex ante designed internationally comparative empirical research. In Report prepared for the Metropolis International Steering Committee, manuscript. 2001.

HOFFMANN-NOWOTNY, Hans-Joachim. Soziologie des Fremdarbeiterproblems: Eine theoretische und empirische Analyse am Beispiel der Schweiz. Stuttgart: Erike, 1973.

HONDRICH, Karl Otto. Wovon wir nichts wissen wollten. Die Zeit, č. 40, 1992. ISSN 0044-2070. 
IMHOF, Kurt. Nationalism and the theory of society. In WICKER, H. R. (eds.) Rethinking nationalism and ethnicity: the struggle for meaning and order in Europe. Oxford: Berg, 1997, s. 57-72. ISBN 1-85973-926-1.

JESSOP, Bob. Reflections on globalization and its (il)logic(s). In OLDS, K., DICKEN, P., KELLY, P., KONG, L., WAI-CHUNG YEUNG, H. (eds.) Globalization and the AsiaPacific: contested territories. London: Routledge, 1999, s. 19-38. ISBN 0-41519-920-4.

KARAKASIDOU, Anastasia N. Sacred scholars, profane advocates: intellectuals molding national consciousness in Greece. Identities, 1994, č. 1, s. 35-62.

KEARNEY, Michael. Borders and boundaries of the state and self at the end of empire. Journal of Historical Sociology,1991, č. 4, s. 52-74. ISSN 0952-1909.

KWONG, Peter. The new Chinatown. New York: Hill and Wong, 1987, 210 s. ISBN 0-80907-255-6.

LEBOVICS, Herman. True France: the wars over cultural identity, 1900-1945. Ithaca, NY: Cornell University Press, 1992.

LEMELLE, Sidney; KELLEY, Robin. Imagining home: class, culture and nationalism in the African Diaspora. London: Verso, 1994. 384 s. ISBN 0-86091-585-9.

LESSER, Jeffrey. Negotiating national identity: immigrants, minorities and the struggle for ethnicity in Brazil. Durham, NC: Duke University Press, 1999. 304 s. ISBN 0-82232-292-7.

LEVITT, Peggy. Transnationalizing community development: the case of migration between Boston and the Dominican Republic. Nonprofit and Voluntary Sector Quarterly, 1997, č. 26, s. 509-526. ISSN 0899-7640.

LIEBERSON, Stanley. A piece of the pie: black and white immigrants since 1880. Berkeley: University of California Press, 1981. 420 s. ISBN 0-52004-362-6.

LIST, Frederick. National system of political economy. New York: Garland, 1974/1856.

LUTON, Harry. The satellite/metropolis model: a critique. Theory and Society, 1976, č. 3, s. 573-581. ISSN 0263-2764.

McCRONE, David. The sociology of nationalism. London: Routledge, 1998. 224 s. ISBN 041511-460-8.

MAHLER, Sarah. Theoretical and empirical contributions toward a research agenda for Transnationalism. In SMITH, M. P., GUARNIZO, L. E. (eds.) Transnationalism from below. New Brunswick, NJ: Transaction Publishers, 1998, s. 64-100. ISBN 1-56000-990-X.

MANN, Michael. The sources of social power, volume II: the rise of classes and nation-states, 1760-1914. Cambridge: Cambridge University Press, 1993. 828 s. ISBN 0-52144-585-X.

MARTINS, Herminio. Time and theory in sociology. In REX, J. (eds.) Approaches to sociology: an introduction to major trends in British sociology. London, Boston: Routledge, Kegan Paul, 1974, s. 246-294. ISBN 0-71007-824-2.

Mayall, James. Nationalism and international society. Cambridge: Cambridge University Press, 1990. 184 s. ISBN 0-52138-961-5.

MEILLASSOUX, Claude. Gegen eine Ethnologie der Arbeitsmigration. In J. BLASCHKE, J., GREUSSING, K. (eds.) Dritte Welt in Europa, Frankfurt: Syndikat, 1980, s. 53-59. ISBN 3-81080-148-8. 
MITTLEMAN, James. The dynamics of globalization. In MITTLEMAN, J. (eds.) Globalization: critical reflections. Boulder, CO: Lynne Reinner, 1996, s. 1-20. ISBN 1-55587-752-4.

MITTLEMAN, James. How does globalization really work? In MITTLEMAN, J. (eds.) Globalization: critical reflections. Boulder, CO: Lynne Reinner, 1996, s. 21-32. ISBN 1-55587-752-4.

MORAWSKA, Ewa. The new-old transmigrants, their transnational lives and ethnicization: a comparison of 19 th/20th and 20th/21st C. situations. In MOLLENKOPF, J., GERSTLE, G. (eds.) Immigrants, civic culture and modes of political incorporation. New York: Sage, Social Science Council, 2001, s. 175-211.

NICULESCU, Gheorghe Alexandru. Nationalism and the representation of society in Romanian Archaeology. In A. OROVEANU, A. (eds.) Nation and national ideology: past, present and prospects, Bucharest: New Europe College. [forthcoming].

NODIA, Ghia. Nationalism and democracy. Journal of Democracy, 1992, roč. 3, č. 4, s. 3-22. ISSN 1045-5736.

NORDMAN, Daniel. Des limites d'etat aux frontiěres nationales. In NORA, P. (eds.) Les lieux de memoire: la nation, Vol. 1. Paris: Gallimard, 1997, s. 1125-1146. ISBN 2-07074-902-9.

NYIRI, Pál. New Chinese migrants in Europe: the case of the Chinese community in Hungary. Aldershot: Ashgate, 1999. ISBN 0-75461-154-X.

ONG, Aihwa. A momentary glow of fraternity: narratives of Chinese nationalism and Capitalism. In GLICK SCHILLER, N. (eds.) Narratives of capitalism, Special issue of Identities, 1997, č. 3, s. 331-366.

ONG, Aihwa. Flexible citizenship: the cultural logic of transnationality. Durham, NC: Duke University Press, 1999. 336 s. ISBN 0-82232-269-2.

ONG, Aihwa; NONINI, Donald. (eds.) Ungrounded empires: the cultural politics of Chinese Transnationalism. New York: Routledge, 1997, 352 s. ISBN 0-00591-542-2.

PANITCH, Leo. Rethinking the role of the state. In MITTLEMAN, J. (eds.) Globalization: critical Reflections. Boulder, CO: Lynne Reinner, 1996, s. 83-113. ISBN 1-55587-752-4.

PANITCH, Leo. The new imperial state. New Left Review, 2000, č. 2, s. 5-20. ISSN 00286060.

PAPASTERGIADIS, Nikos. The turbulence of migration: globalization, deterritorialization and Hybridity. Cambridge: Polity Press, 2000. 256 s. ISBN 0-74561-431-0.

PARK, Robert Erza. Race and culture. Glencoe, IL: Free Press, 1950.

PARK, RobertErza. Immigrant community and immigrant press and its control. In HUGHES, E., JOHNSON, C., MASUOKA, J., REDFIELD, R., WIRTH, L. (eds.) The collected papers of Robert Park, New York: Arno, 1974/1925, s. 152-164.

PORTES, Alejandro; GUARNOZO, Luis E.; LANDOLT, Patricia (eds.) Transnational communities. Special issue of Ethnic and Racial Studies, 1999, roč. 22, č. 2. ISSN 0141-9870.

POTTS, Lydia. The world labour market: a history of migration. London: Zed Books, 1990. 304 s. ISBN 0-86232-883-7. 
RADTKE, Frank Olaf. Fremde und Allzufremde. Zur Ausbreitung des ethnologischen Blicks in der Einwanderungsgesellschaft. In WICKER, H. R., ALBER, J. L., BOLZMAN, C., FIBBI, R., IMHOF, K., WIMMER, A. (eds.) Das Fremde in der Gesellschaft: Migration, Ethnizität und Staat. Zurich: Seismos, 1996, s. 333-352. ISBN 3-40785-765-1.

RAFAEL, Vicente. Discrepant histories: translocal essays on Filipino cultures. Philadelphia: Temple University Press, 1995. 331 s. ISBN 9-71270-385-1.

RAVENSTEIN, Ernst G. The laws of migration: second paper. Journal of Royal Statistical Society, 1889, č. 52, s. 241-305. ISSN 0952-8385.

REDDING, John. Inside the Democratic Party, Indianapolis: Bobbs-Merrill, 1958.

RENAN, Ernest. Que'est-ce qu' une nation? In Oeuvres completes, vol. 1. Paris: CalmannLevy, 1958, s. 887-990.

RODGERS, Daniel. Atlantic crossings: social politics in a progressive age. Cambridge, MA: Belknap Press of Harvard, 1998. 648 s. ISBN 0-67405-131-9.

ROUSE, Roger. Mexican migration and the social space of postmodernism. Diaspora, 1991, č. 1, s. 8-23.

ROUSE, Roger. Making sense of settlement: class transformation, cultural struggle and transnationalism among Mexican migrants in the United States. In N. GLICK SCHILLER, N., BASCH, L., BLANCl-SZANTON, C. (eds.) Towards a transnational perspective on migration: race, class, ethnicity and nationalism reconsidered. New York: New York Academy of Sciences, 1992, s. 25-52. ISBN 0-89766-703-4.

RUMBAUT, Ruben G.; CORNELIUS, Wayne A. (eds.) California's immigrant children: theory, research and implications for educational policy. San Diego: Center for USMexican Studies, University of California, San Diego, 1995. 272 s. ISBN 1-87836-717-X.

SASSEN, Saskie. Losing control: sovereignty in an age of globalization. New York: Columbia, 1996. 128 s. ISBN 0-23110-608-4.

SASSEN, Saskie. Guests and aliens. New York: New Press, 1999. 256 s. ISBN 1-56584-481-0.

SASSEN, Saskie. Cracked casings: notes towards an analytics for studying transnational Processes. In PRIES, L. (eds.) New transnational social spaces. London: Routledge, 2001, s. 187-207. ISBN 0-41523-736-X.

SCHERMERHORN, Richard Alonzo. These our people: minorities in American culture. Boston, MA: DC Heath and Company, 1949.

SCHNAPPER, Dominique. La France de I 'integration: sociologie de la nation en 1990. Paris: Gallimard, 1991. 374 s. ISBN 2-07072-174-4.

SEN, Amartya. Reason before identity. Oxford: Oxford University Press, 1999. 31 s. ISBN 0-19951-389-9.

SILVERMAN, Maxim. Rights and difference: questions of citizenship in France. In HARGREAVES, A., LEAMEN, J. (eds.) Racism, ethnicity, and politics in contemporary Europe. Aldershot: Edward Elgar, 1995. s. 253-263. ISBN 1-85278-838-0.

SKRBIS, Zlatko. Long distance nationalism: diasporas, homelands and identities. Aldershot: Ashgate, 1999. 201 s. ISBN 1-85972-672-0.

SMART, A. Capitalist story-telling and hegemonic crises: some comments. Identities, 1997 , č. 3, s. 399-112. 
SMITH, Adam. An inquiry into the nature and causes of the wealth of nations. Oxford: Oxford University Press, 1983/1789.

SMITH, Anthony D. Nationalism and social theory. British Journal of Sociology, 1983, roč. 34, č. 1, s. 19-38. ISSN 0007-1315.

SMITH, Anthony D. Nations and nationalism in a global era. Cambridge: Polity Press, 1995. 216 s. ISBN 0-74561-019-6.

SMITH, Anthony D. Nationalism and modernism: a critical survey of recent theories of nations and nationalism. London: Routledge, 1998. 272 s. ISBN 0-41506-341-8.

SMITH, Michael P.; GUARNIZO, Luis E. (eds.) Transnationalism from below: comparative urban and community research, 6. New Brunswick, NJ: Transaction Publishers, 1998. 316 s. ISBN 1-56000-990-X.

SMITH, Robert. Transnational migration, assimilation, and political community. In CRAHAN, M., VOURVOULIAS-BUSH, A. (eds.) The city and the world. New York: Council on Foreign Relations, 1997, s. 110-132. ISBN 0-87609-208-3.

SMITH, Robert. Transnational localities:community, technology and the politics of membership within the context of Mexico-US migration. In SMITH, M. P., GUARNIZO, L. E. (eds.) Transnationalism from below: comparative urban and community research $6, \mathrm{New}$ Brunswick, NJ: Transaction Publishers, 1998, s. 196-241. ISBN 1-56000-990-X.

SNYDER, Jack L. From voting to violence: democratization and nationalist violence. New York: Norton, 2000. 320 s. ISBN 0-39397-481-2.

STEINBERG, Stephen. The ethnic myth: race, ethnicity and class in America. Boston: Beacon Press, 1989. 317 s. ISBN 0-80704-151-3.

STALER, A. Making empire respectable: the politics of race and sexual morality in 20th century colonial cultures. American Ethnologist, 1989, roč. 16, s. 634-660. ISSN 0094-0496.

SZANTON BLANC, Cristina. A thoroughly modern Asian: capital, culture and nation in Thailand and the Philippines. In ONG, A., NONINI, D. (eds.) Ungrounded empires: the cultural politics of Chinese transnationalism, New York: Routledge, 1996, s. 261-286. ISBN 0-41591-543-0.

TAGUIEFF, Pierre-André. Le „nationalisme des nationalists“: un probléme pour l'histoire des idées politiques en France. In DELANNOI, G., TAGUIEFF, P. A. (eds.) Theories du nationalisme. Paris: Editions Kimé, 1991, s. 47-174. ISBN 2-90821-210-2.

TAYLOR, Peter J. Embedded statism and the social sciences: opening up to new spaces. Environment and Planning A, 1996, roč. 28, č. 11, 1917-1928. ISSN 0308-518X.

THERBORN, Göran. European modernity and beyond: the trajectory of European societies, 1945-2000. London: Sage, 1995. 416 s. ISBN 0-80398-935-1.

THOMPSON, Andrew; FEVRE, Ralph. The national question: sociological reflections on nation and nationalism. Nations and Nationalism. 2001, roč. 7, č. 3, s. 297-315. ISSN 1354-5078.

TORPEY, John. The invention of the passport: surveillance, citizenship and the state. 1. vyd. Cambridge: Cambridge University Press, 2000. 224 s. ISBN 0-52163-493-8.

TRIBALAT, Michele. Faire France: une grande enquéte sur les immigrés et leurs enfants. Paris: Editions La Découverte, 1995. 231 s. ISBN 2-70712-449-4. 
TURE, Kwame; HAMILTON, Charles. Black Power: the politics of liberation in America. New York: Vintage Books, 1992. 256 s. ISBN 0-67974-313-8.

URRY, John. Sociology beyond societies. 1. vyd. London: Routledge, 2000. 272 s. ISBN 0-41519-089-4.

VETROVEC, Steven. (eds.) Migration and social cohesion. 1. vyd. Aldershot: Edward Elgar, 1999. 534 s. ISBN 1-85898-868-3.

von HAYEK, Friedrich A. Scientism and the study of society. Economica, 1943, roč. 10, s. 34-63. ISSN 0013-0427.

WALDINGER, Rogers. The sociology of immigration: second thoughts and reconsiderations, keynote address prepared for the conference on migration and development. Princeton University, 2000.

WALLERSTEIN, Immanuel. Africa: the politics of independence. New York: Vintage, 1961.

WALLERSTEIN, Immanuel. The modern world-system: capitalist agriculture and the origins of the European world-economy in the sixteenth century. New York: Academic Press, 1974. $410 \mathrm{~s}$.

WEED, Perry. The white ethnic movement and ethnic politics. New York: Praeger, 1973. $274 \mathrm{~s}$.

WENT, Robert. Globalization: neoliberal challenges, radical responses. London: Pluto, 2000. 176 s. ISBN 0-74531-422-8.

WILLIAMS, Brackette F. A class act: anthropology and the race to nation across ethnic terrain. Annual Review of Anthropology, 1989, roč. 18, 401-144. ISSN 0084-6570.

WILSON, Thomas; DONNAN, Hastings. (eds.) Border identities: nation and state at the international Frontier. Cambridge: Cambridge University Press, 1998. 313 s. ISBN 0-52158-745-X.

WIMMER, Andreas. L'héritage de Herder: nationalisme, migrations et la pratique théorique de l'anthropologie. Tsantsa: Revue de laSociété Suisse d'Ethnologie, 1996, č. 1, s. 4-18. ISSN 1420-7834.

WIMMER, Andreas. L'Etat-nation: une forme de fermeture sociale. Archives Européennes de Sociologie. 1996, roč. 37, s. 163-179. ISSN 0003-9756.

WIMMER, Andreas. Binnenintegration und Aussenabschliessung: zur Beziehung zwischen Wohlfahrtsstaat und Migrationssteuerung in der Schweiz des 20 Jahrhunderts. In BOMMES, M. HALFMANN, J. (eds.) Migration in nationalen Wohlfahrtsstaaten: Theoretische und vergleichende Untersuchungen. Osnabrück: IMIS, 1998, s. 199-221. ISBN 3-93214-720-0.

WIMMER, Andreas. Zurich's Miami: transethnic relations of a transnational community. Transnational Communities Working Paper WP-98-07. Oxford: Institute for Social and Cultural Anthropology, 1998.

WIMMER, Andreas. Verwischte Grenzen: Zum Verhältnis zwischen Soziologie, Ethnologie und Volkskunde. In GIORDANO, C. (eds.) Borderlines: Soziologie, Kulturanthropologie und Ethnologie. Annali di Sociológia - Soziologisches Jahrbuch, 1999, č. 12.

WIMMER, Andreas. Globalizations avant la letter: a comparative view on isomorphization and heteromorphization in an interconnecting world. Comparative Studies in Society and History, 2001, roč. 43, s. 435-466. ISSN 0010-4175. 
WIMMER, Andreas. Modernisation as a case of transformation. In ELWERT, G., M. KOHLI, M., KRAUTH, W. H., SCHELKE, W. (eds.) Paradigms of social change: modernisation, development, transformation, evolution. Frankfurt: Campus, 2001, s. 77-89. ISBN 0-31223-394-9.

WIMMER, Andreas. Nationalist exclusion and ethnic conflict: shadows of modernity. 1. vyd. Cambridge: Cambridge University Press, 2002. 332 s. ISBN 0-52101-185-X.

WOLF, Eric R. Europe and the people -without history. 1. vyd. Berkeley: University of California Press, 1982. 534 s. ISBN 0-52004-898-9.

WYMAN, Mark. Round-trip to America: the immigrants return to Europe 1880-1930. Ithaca, NY: Cornell University Press, 1993. 267 s. ISBN 0-80142-875-0.

ZOLBERG, Aristide R. The formation of new states as a refugee-generating process. The Annals of American Academy of Political and Social Science, 1983, roč. 467, č. 1, s. 24-38. ISSN 0002-7162.

\section{Autor a autorka}

Andreas Wimmer působí od roku 2003 jako profesor sociologie na Kalifornské univerzitě v Los Angeles (University of California). V letech 1999-2002 pracoval jako zakládající ŕeditel Centra pro rozvojový výzkum (Center for Development Research) na Bonnské universitě (Die Universität Bonn). Jeho výzkumnými zájmy jsou dynamika formace národního státu, vytváření etnických hranic a politický konflikt v komparativní perspektivě. V rámci svých studií kulturní a sociální změny vyvinul model kulturního vyjednávání a kompromisu.

Kontakt: awimmer@soc.ucla.edu

Nina Glick Schiller je ředitelkou Institutu kosmopolitních kultur (Cosmopolitan Cultures Institute) na Manchesterské univerzitě (University of Manchester). Předtím působila jako profesorka antropologie na University of New Hampshire v americkém Durhamu. Zabývá se zejména migrací a transnacionálními procesy a sociálními vztahy. Její aktuální publikace polemizují s metodologickým nacionalismem většiny migračních studií tím, že rozvíjejí migrační teorii zkoumáním vztahu mezi migrantem a městem.

Kontakt: nina.glickschiller@manchester.ac.uk 